\title{
Zé Zabel Perna-de-Pau: perspectiva histórico-antropológica sobre uma tradição oral tapeba
}

\section{Zé Zabel Perna-de-Pau: a historical-anthropological perspective on a tapeba oral tradition}

Henyo Trindade Barretto Filho*

*Universidade de Brasília - Brasília, DF, Brasil

henyo@unb.br

https://orcid.org/0000-0003-3845-9936 


\title{
Resumo
}

Trata-se de (re)construir, a partir de testemunhos orais de índios e não índios e de algum repertório documental, a trajetória de um importante líder indígena do povo tapeba, que se destacou na primeira metade do século XX: José "da Isabel" Alves dos Reis, ou Zé Zabel Perna-de-Pau. Baseado no repertório conceitual e metodológico proposto por Vansina (1965) e inspirado em obras etnobiográficas (Albert, 2015) e na noção de "biografia social" (Werbner, 1991 apud Jimeno Santoyo, 2006, p. 48), trato o conjunto de narrativas sobre Perna-de-Pau como uma tradição oral. Ao (re)construir a sua trajetória - características físicas e condutas pessoais, talentos e habilidades, redes de parentesco e de relações estabelecidas, estilo e alcance de liderança, e enraizamento territorial - pretendo expor aspectos importantes dos modos de vida tapeba e suas expressões territoriais na primeira metade do século XX, e certas dimensões de como se pensam como povo distinto e vivem no território que lutam para reconquistar.

Palavras-chave: tapeba; povo indígena; tradição oral; biografia social.

\begin{abstract}
Based on oral testimonies of indigenous and non-indigenous peoples, alongside documentary sources, this article is a (re)construction of the trajectory of an important indigenous leader of the Tapeba people, who stood out in the first half of the twentieth century: José “da Isabel” Alves dos Reis, or Zé Zabel Perna-de-Pau (wooden leg). Grounded on Vansina's (1965) conceptual and methodological repertoire and inspired by ethnobiographical oeuvres (Albert, 2015) and the notion of "social biography" (Werbner, 1991 apud Jimeno Santoyo, 2006, p. 48), I treat the set of narratives about Perna-de-Pau as an oral tradition. By (re)building his trajectory - physical characteristics and personal conduct, talents and skills, networks of kinship and relationships, leadership style and range, and territorial rooting - I wish to unveil important aspects of tapeba lifestyles and territorial expressions in the recent past, and dimensions of how they think of themselves as a distinct people and live in the territory they struggle to recover.
\end{abstract}

Keywords: tapeba; indigenous people; oral tradition; social biography. 
Como reza toda tradição

É tudo uma grande invenção.

"Mistério do Samba" (Fred 04 e Pianinho)

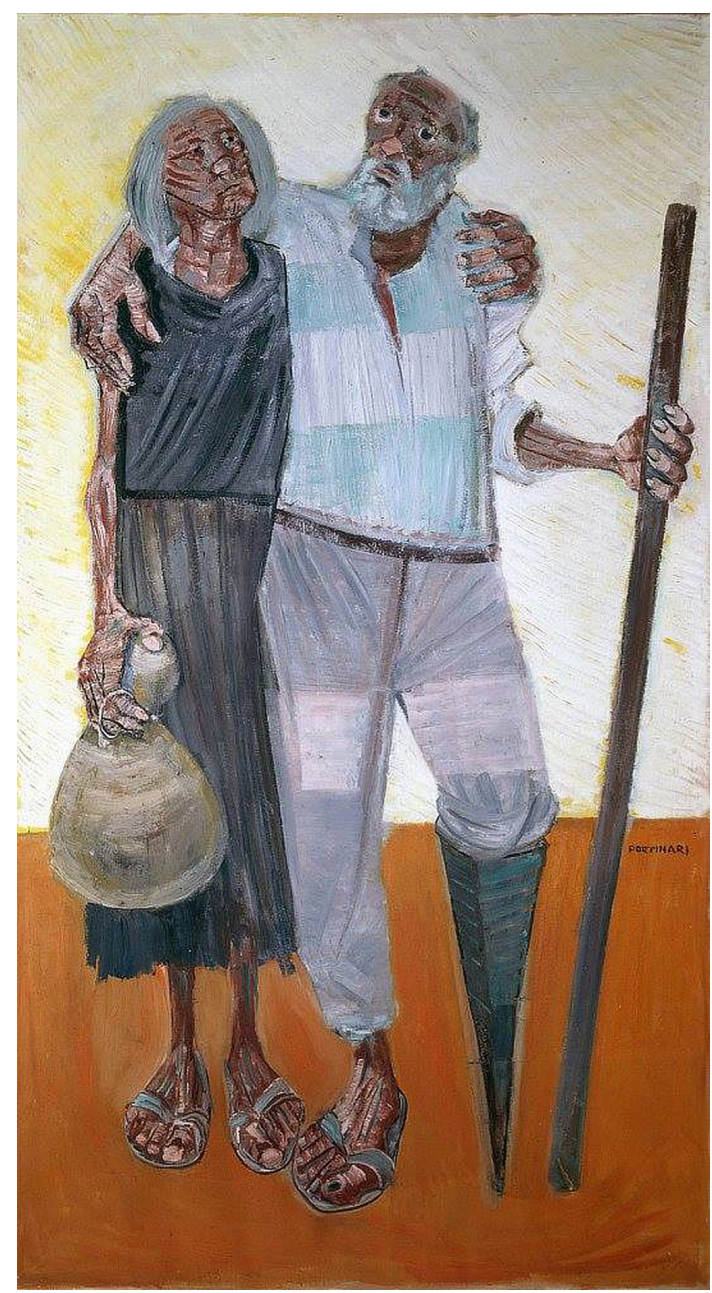

Figura 1. O perna-de-pau e sua senhora, de Candido Portinari (1959). Museu Assis Chateaubriand (MAC) da Universidade Estadual da Paraíba (UEPB), Campina Grande (PB). ${ }^{1}$

1 Obra estimada em R\$ 5 milhões. Ver MAC... (2012). 


\section{Introdução ${ }^{2}$}

Este trabalho se inspira nas obras etnobiográficas (ver balanço crítico em Albert, 2015) e na noção de "biografia social" (Werbner, 1991 apud Jimeno Santoyo, 2006, p. 48) em seu propósito de (re)construir, a partir de testemunhos orais de índios e não índios e de algum repertório documental, a trajetória de um importante líder indígena do povo tapeba, ${ }^{3}$ que se destacou na primeira metade do século XX: José "da Isabel" Alves dos Reis, mais conhecido como Zé Zabel Perna-de-Pau. Baseado no repertório conceitual e metodológico proposto por Vansina (1965), entendo esse conjunto aparentemente disparatado de testemunhos como constituindo uma tradição oral - como argumentarei adiante.

Um ilustre desconhecido, mas merecedor de um curtíssimo verbete na galeria de "biografias indígenas" de Geraldo Almeida (1988),, Perna-de-Pau - termo também usado como etnônimo na paisagem social local do distrito da sede do município de Caucaia, na Zona Metropolitana de Fortaleza, Ceará - foi o apelido de um ancestral que residiu no lugar denominado Paumirim e aos quais (ancestral e lugar) muitos tapebas remontam ao traçarem suas genealogias no que concerne a pelo menos um grupo de cognatos, os chamados "Zabel".

2 Uma primeira versão deste trabalho, intitulada 'Zé Zabel Perna-de-Pau: um 'herói indígena' Tapeba?", foi apresentada no Simpósio Temático $\mathrm{n}^{\circ} 6$ - Biografias e histórias de vida como porta de entrada para a compreensão de povos indígenas do $3^{\circ}$ Congresso Internacional Povos Indígenas da América Latina, realizado em julho de 2019, na Universidade de Brasília. Agradeço ao Prof. João Pacheco de Oliveira, coordenador do simpósio, pela oportunidade e pelos comentários feitos na ocasião, que tentei incorporar na versão submetida à revista. Agradeço igualmente aos pareceristas anônimos pelos pertinentes comentários, que também procurei incorporar e contribuíram para aprimorar o artigo. Eventuais equívocos que tenham permanecido são de minha inteira responsabilidade.

3 A grafia de nomes indígenas segue a aqui as orientações de Melatti $(1979,1989)$ e as críticas deste à "Convenção para a Grafia de Nomes Tribais", estabelecida pela ABA, no Rio de Janeiro, em 1953. Levo em consideração, também, as sugestões de Handler (1985) quanto à cautela retórica ao narrar fenômenos da ordem do nacionalismo e da etnicidade. Reservo a letra inicial em caixa-alta (T) aos topônimos e às citações de textos nos quais o nome aparece grafado dessa maneira. Assim, mantive o nome da coletividade em questão grafado segundo a ortografia oficial brasileira, com a inicial em minúscula $(\mathrm{t})$ e usando inclusive o $s$ para fazer-lhe o plural.

4 "Perna de Pau - Cacique tapeba do município de Caucaia, no Ceará. Depois da sua morte, ocorrida há pouco mais de vinte anos, os tapebas ficaram sem liderança, perdendo gradativamente suas terras, com grave ameaça à sua precária sobrevivência" (Almeida, G., 1988, p. 103). Ver também no portal Os Brasis e suas memórias: https://osbrasisesuasmemorias.com.br/perna-de-pau/. 
Nunca antes me ocorreu contar a história de Perna-de-Pau, por mais ubíquas que fossem as referências a ele nas narrativas tapebas sobre o passado. O estímulo para fazê-lo veio do meu vínculo à rede de pesquisadores colaboradores do projeto Os Brasis e suas memórias e do incentivo do seu coordenador, João Pacheco de Oliveira. Conhecedor de Perna-de-Pau por meio dos meus trabalhos, ele avaliou que uma biografia deste poderia ser uma contribuição singular ao projeto em tela. Este, por meio de biografias indígenas, tem "por objetivo desconstruir narrativas e imagens consolidadas por histórias nacionais acerca das populações autóctones" e "produzir dados que contribuam para a compreensão da continuada e persistente presença da população indígena, não só no período colonial e no século XIX, mas no Brasil atual" (Os Brasis..., 2017).

Esta minha contribuição tardia ao projeto, contudo, difere de outras em que etnobiografias são construídas "a partir da elaboração de memórias decorrentes de investigações colaborativas, experiências dialógicas e etnografias compartilhadas" (Os Brasis..., 2017). Como se verá a seguir, meus encontros com os tapebas não se encaixam nessas definições. Este exercício se aproxima mais de uma meta-narrativa elaborada a partir do cotejo e sistematização de múltiplas narrativas, para contar uma história com o objetivo de compreender fenômenos socioculturais particulares contemporâneos - movimento que penso estar autorizado pela existência de uma tradição oral tangível sobre Perna-de-Pau (o que pretendo demonstrar).

No espírito deste número temático e da antropologia histórica que o anima, tento enveredar no duplo movimento epistemológico de tratar o passado como problema etnográfico para analisar situações atuais como problema histórico. Ao (re)construir a trajetória de Perna-de-Pau - características físicas e condutas pessoais salientes, talentos e habilidades notáveis, redes de parentesco e de relações estabelecidas, estilo e alcance de liderança, e enraizamento territorial (as terras tradicionalmente ocupadas por sua parentela) - pretendo abrir janelas para compreender: (i) aspectos importantes dos modos de vida tapebas e suas expressões territoriais na primeira metade do século XX; e (ii) algumas dimensões de como estes se pensam hoje como povo distinto e vivem no território que lutam para reconquistar integralmente há cerca de 40 anos.

Para lograr isso, este texto se organiza, após esta breve introdução, em quatro partes que enfocam aspectos constitutivos da vida e da pessoa de Perna-de-Pau, tal como lembrada por muitos interlocutores - testemunhos e memórias que, 
como veremos, são muito consistentes entre si. Antes, porém, abordo dimensões teórico-metodológicas e contextuais que julgo relevantes para lastrear este exercício.

\section{"Digo porque conheci" e/ou "eu ouvi dizer": entre testemunhos oculares e orais}

Esta análise enfoca intencional e prioritariamente o nível local, dado seu intuito de desobscurecer esse protagonista indígena. Ela não deixa, contudo, de articular processos, dinâmicas, relações e posições relevantes a outras escalas para a compreensão das memórias e histórias indígenas aqui trazidas, e da trajetória (noção importante aqui - ver adiante) de Perna-de-Pau - como, por exemplo, a escala regional, dadas as relações dele com segmentos da elite política estadual (como veremos a seguir), e a nacional, visto que foi no contexto de demarcação da Terra Indígena Tapeba que muitas dessas memórias e histórias foram mobilizadas. Daí porque enfatizo nesta seção algumas dimensões contextuais e teórico-metodológicas sobre história oral, memória, entrevistas e etnografia, que considero relevantes para situar as condições nas quais a história particular de - ou as histórias peculiares sobre - Perna-de-Pau foi relatada, apreendida e registrada, e que influíram na sua sistematização escrita neste texto.

Em primeiro lugar, entendo esse exercício como uma (re)construção, por duas razões, pelo menos. Primeiro por tratar-se - de minha parte - de montar um quebra-cabeças a partir de peças disponíveis e dispersas em distintas fontes orais (mas também escritas), para esboçar a trajetória desse líder inconteste e central na história recente tapeba. Se este não chega a ser exatamente um exercício de ilusionismo biográfico (parafraseando Bourdieu, 2002) - ou seja, de imposição de sentido, ao pintar de modo coerente um quadro que, na minha experiência com os tapebas, se apresentou de modo fragmentário e emaranhado nas memórias (entre testemunhos oculares e orais) de indígenas de diferentes gerações - não deixa de ser um exercício de biografia social, que tenta dar conta de diferentes contextos e processos sociais, pondo para dialogar vários interlocutores em uma "narrativa de narrativas" (Werbner, 1991 apud Jimeno Santoyo, 2006, p. 48 e ss.).

Segundo, por tratar-se uma construção de segundo nível - portanto, uma reconstrução -, pois aqui sistematizo e rearticulo elementos que já apresentei 
de outros modos em trabalhos anteriores, resultantes de inserções de caráter distinto e que não tinham a intenção específica deste artigo. Refiro-me à minha dissertação de mestrado (Barretto Filho, 1993) e ao relatório de identificação da Terra Indígena Tapeba (Barretto Filho, 2005), que resultaram de distintos e variados trabalhos de campo, com objetivos diferentes. Baseio-me, assim, numa interação intermitente com os tabebas ao longo de mais de 30 anos em diferentes contextos de pesquisa e de incidência. $O$ que os tapebas sabiam mais de 30 anos atrás sobre Perna-de-Pau, quando os encontrei pela primeira vez, e o que sabem hoje, resulta de um processo multissituado de construção coletiva de sentido sobre a trajetória daquele líder, urdida pelos próprios índios, uns mais interessados (professores e lideranças), outro menos, mas todos igualmente posicionados nesse processo. Importa notar que a quase totalidade das pessoas com as quais conversei desde meados dos anos 1980, e que têm trechos de seus depoimentos aqui transcritos, já faleceram. Isso faz com que tais depoimentos/testemunhos assumam, hoje, deslocados e distantes dos contextos em que foram produzidos, um valor histórico singular - o que é mais uma justificativa para este exercício.

Assim, a análise que conforma este exercício de reconstrução baseia-se em discussões teórico-metodológicas em torno da história oral, da memória, de formas de entrevista e do que poderíamos chamar de uma etnografia histórica.

Para começar, reconhecemos as tradições orais como fontes fidedignas de informação sobre o passado, tal como admitido por Vansina em seu estudo de metodologia histórica inspirado na literatura etnológica, cujas definições e orientações seguimos. Para Vansina, uma tradição é uma corrente (ou cadeia no sentido de encadeamento) de testemunhos, na qual cada um destes forma um elo por meio de cada narrador/a. Uma tradição oral consistiria, assim, no conjunto de testemunhos verbais/orais que são relatos sobre o passado (reported statements concerming the past) - definição que implicaria que nada além de tradições orais entrassem em consideração, ou seja, relatos falados e/ou cantados (Vansina, 1965, p. 9-21). ${ }^{5}$ Testemunhos verbais/orais difeririam, assim, dos testemunhos oculares e são definidos como "o conjunto de declarações feitas por qualquer informante individual acerca de uma única série de eventos, na

5 Todas as paráfrases e citações de Vansina em português correspondem a traduções livres minhas. 
medida em que todas as declarações reportem ao mesmo referente" (Vansina, 1965, p. 22).

Nesse sentido, no caso de referentes como Perna-de-Pau e a terra da santa, ${ }^{6}$ tudo se passa como se estivéssemos diante de tradições orais genuínas - ou seja, conjunto de relatos orais sucessivos relativamente consistentes sobre um mesmo referente - e não reapropriações de fatos estabelecidos por fontes escritas socializadas pelas agências que atuam localmente. Isso porque muitos testemunhos foram produzidos nos diferentes períodos de campo em conversas informais e entrevistas semiestruturadas ${ }^{7}$ com pessoas idosas, iletradas, que não eram participantes ativas do movimento etnopolítico e nem foram alcançadas pelo progressivo processo de escolarização, que teve lugar entre os tapebas desde meados dos anos 1990. A existência de tais correntes de transmissão de testemunhos orais, mormente junto a tapebas iletrados e idosos, evidenciou-se no modo como habitualmente começavam seus relatos sobre o passado.

Nós já estamos contando o que já estamos vendo contar hoje em dia, né? Dos passados que nós passamos. (Dona Meire, 69 anos, lagoa do Tapeba, Cutia, 1992).

O que eu conheci. O que me diziam. Eu não sei, né? Eu também não vou contar uma história certa. Eu não sei. Eu era mais nova. (Dona Chagas, 75 anos, Trilho, Paumirim, 1992).

O que nós contamos, nós já estamos contando o que a gente já ouviu os mais velhos contar. Eu conto do que eu já ouvi contar. (Zuíla, 54 anos, Trilho, Paumirim, 1992).

6 Categoria cultural de referência ao patrimônio territorial da aldeia de Nossa Senhora dos Prazeres de Caucaia, a que aludem para, entre outras coisas, marcar pertencimento territorial e referir-se às formas de apropriação relativamente comuns da terra que viveram no passado (ver Barretto Filho, 1993, 2005).

7 Segundo Vansina, um relato oferecido em resposta a um conjunto de questões deve ser considerado o trabalho e o produto de dois interlocutores: quem pergunta - via de regra, o/a pesquisador/a - e a pessoa interpelada. O testemunho consiste, de fato, não só das respostas, mas também das perguntas dirigidas à pessoa interpelada. É possível, assim, distinguir dois tipos de pergunta: as que indicam e as que não indicam o tipo de resposta esperada - estas constituindo apenas convites para prover informações, tendo pouca influência sobre as respostas (Vansina, 1965, p. 29-30). Foi deste último modo que tentei me conduzir ao interpelar os tapebas nos diferentes contextos de campo, procurando intervir o mínimo possível em seus modos próprios de relatar. 
Importa notar que o estudo de Vansina de metodologia histórica estava baseado em tradições orais ainda vivas entre povos africanos sem escrita, situações nas quais essas fontes teriam preservado, segundo ele, a "natureza essencial da tradição oral" melhor do que tradições encontradas em sociedades com escrita. Nas situações por ele estudadas, a tradição oral não teria sido suplantada, nem ainda separada de seu "contexto natural" e nem suas funções teriam sido superadas pelos documentos escritos. Vansina desconsidera, assim, contextos políticos intersocietários marcados por complementaridades, interdependências e relações de subordinação das tradições orais à escrita. Os casos de sociedades "nas quais a escrita tomou lugar central" (Vansina, 1965, p. 2) são vistos negativamente por ele, como situações descaracterizadoras da "natureza essencial" das tradições orais. Julgo, entretanto, que junto a grupos sociais que reconhecem a existência e o poder da escrita, mas nos quais o letramento não é ubíquo, as sugestões metodológicas de Vansina para o tratamento de fontes orais são relevantes, não só em termos das precauções adotadas, mas também das reflexões sobre a nova situação social em que surge o "testemunho final": a situação de pesquisa, em que alguém registra o que, até então, nunca o foi. ${ }^{8}$

Nesse sentido, advirto que muitas situações de entrevista, como veremos adiante, se constituíram em contextos de transmissão informais, livres e não regulados de relatos sobre o passado, especialmente quando feitas na presença de familiares de gerações descendentes dos interlocutores e de uma audiência indígena ampliada. ${ }^{9}$ Isso significa dizer que, nessas situações, foram transmitidas pelas testemunhas - por meio da linguagem e de uma pessoa para outras de gerações diferentes - informações muitas vezes inéditas sobre o passado.

8 Dado o tamanho do artigo, não se evidenciam tanto aqui, quanto em outros textos (Barretto Filho, 1993, 2005), os procedimentos e precauções metodológicos sugeridos por Vansina e que procurei seguir, no sentido de precisar o caráter dos relatos/testemunhos, quais sejam: caracterização dos modos de testemunhar e métodos de transmissão; cotejo e comparação entre testemunhos de informantes distintos sobre o mesmo referente, para captar variações e denominadores comuns; identificação da frequência de repetição, do controle sobre os depoimentos, da intencionalidade e da significância imputada a estes; caracterização da estrutura dos testemunhos e de categorias culturais porventura existentes.

9 Esse foi o caso dos estudos do GT de identificação da TI Tapeba, posto que foram monitorados o tempo todo por uma "Comissão de Acompanhamento Permanente" formada por representantes indígenas de várias aldeias. 
Como nota Benjamin (1985, p. 199-200), se "o narrador retira da experiência o que ele conta: sua própria experiência ou a relatada pelos outros" - como testemunha ocular ou oral, diria Vansina -, ele "incorpora as coisas narradas à experiência dos seus ouvintes". Assim, quando na presença de audiência, os relatos/testemunhos foram, via de regra, potencializados, incitando a memória dos presentes e ensejando a continuidade das tradições orais - testemunhos transmitidos sobre o passado - dos tapebas. ${ }^{10}$

Outro aspecto importante é destacado por Bosi, por sua vez lastreada na noção de "quadros sociais da memória" de Halbwachs (1990): "se lembramos, é porque os outros, a situação presente, nos fazem lembrar" (Bosi, 1979, p. 17). Isto é, "na maior parte das vezes, lembrar não é reviver, mas refazer, reconstruir, repensar, com imagens e ideias de hoje, as experiências do passado" - "memória [...] é trabalho" (Bosi, 1979, p. 17). O fato de as tradições orais poderem ser reconhecidas como fontes fidedignas sobre o passado não elimina o fato de as lembranças serem imagens construídas "pelos materiais que estão, agora, à nossa disposição, no conjunto de representações que povoam nossa consciência atual" (Bosi, 1979, p. 17). Tais considerações são tanto mais importantes quando ponderamos os contextos já referidos em que interpelei meus interlocutores no sentido de recordarem e verbalizarem experiências passadas - em algumas das quais Perna-de-Pau emerge como personagem ubíqua. Tais testemunhos orais/verbais foram tomados, portanto, como atitudes vis-à-vis situações e exigências presentes.

Por fim, inspirado na noção de biografia social, tentando dar conta de diferentes contextos e processos sociais em distintas escalas, este exercício se aproxima também de uma análise de trajetória, nos termos de Bourdieu (2002, p. 189), ou seja: uma "série de posições sucessivamente ocupadas por um mesmo agente [...] num espaço que é ele próprio um devir, estando sujeito a incessantes transformações". Isso explica porque o artigo está organizado não necessariamente em posições ocupadas em estados sucessivos do campo no qual se desenrola o envelhecimento social (como em Bourdieu), mas em dimensões constitutivas desse agente peculiar - parentesco, personalidade, liderança,

10 Em função dos limites editoriais, acabei usando de modo muito parcimonioso os testemunhos indígenas neste artigo. Vi-me obrigado a editar fortemente tais depoimentos, o que leva a perdas de referências contextuais e de cores/sabores das narrativas. 
convivência, território - tal como estas são mobilizadas nas narrativas de meus interlocutores. Sou eu, contudo, que as organizo assim. Ao fazê-lo, incido em uma etnografia histórica, esse tipo distinto de prosa etnográfica, nos termos de Sahlins (1993), que busca sintetizar a experiência de trabalho de campo em uma comunidade com o estudo do seu passado, seja em arquivos, seja explorando suas tradições orais. Segundo ele, etnografias que levam em conta tempo e transformação fornecem uma forma distinta de conhecer o objeto antropológico. A antropologia histórica de Pacheco de Oliveira (1999) reitera que a compreensão das sociedades e culturas indígenas não pode ser conduzida sem uma reflexão crítica e recuperação de sua dimensão histórica - entendida como os eixos espaçotemporais por meio dos quais os indígenas (como Perna-de-Pau) atuam como sujeitos históricos completos.

\section{Ascendência e descendência de Perna-de-Pau: os Zabel e as outras "famílias" de tapeba}

Segundo um depoimento singular que me foi concedido por ocasião do segundo estudo de identificação da TI Tapeba, em dezembro de 2002, pelo senhor João "Padre" Alves de Lima, então com 70 anos, em sua residência no beco do Bode Magro, no Paumirim, José Alves dos Reis, vulgo Zé Zabel Perna-de-Pau, seria filho - com seus dois irmãos, Antônio e Luís - de uma relação consensual extraconjugal do "tronco velho" Antônio Alves dos Reis com uma negra forra chamada Isabel "Torta". Ainda segundo seu João "Padre", os três irmãos teriam trabalhado como seringueiros na Amazônia, um dos quais teria permanecido lá.

João: Sim. Era do tempo dos meus avós. Tinha o meu pai. O meu avô [paterno] tinha duas mulheres, que era minha avó e tinha uma negra velha lá no Tapeba uma morena lá. O meu avô. Ele tinha essa outra mulher lá. Justamente que essa mulher lá, meu avô teve outra família lá. Foi o Perna-de-Pau - chamado Zé Zabel-, Luís Zabel e Antônio Zabel. São três irmãos. Eles foram pro Amazonas. Voltaram o Zé Zabel e o Antônio Zabel. O Luís Zabel ficou por lá. Justamente, o Zé Zabel era dono desse terreno aqui - o Perna-de-Pau. Que era meu tio. O Antônio Zabel era dono daquele terreno ali do Paumirim, da Setrex pra cima. Ali era do 
Antônio Zabel, que era pai do Zé Coco, Firmino, João Zabel, Mané Zabel. Era tudo ali. As heranças todinhas ali. Eles venderam tudo. Perderam a herança. [...] Henyo: Então, explica pra mim uma coisa, seu João. O senhor falou que o seu avô chegou a ter duas companheiras. É isso? Como é que é essa história?

J: É. A companheira verdadeira mesmo era essa minha avó.

H: Mãe do seu pai?

J: Era. A outra era uma velha que morava lá no Tapeba, lá perto da lagoa. Ela não tinha um olho. Era cega. Chamavam ela Isabel Torta. Mas dizem que era uma negrona muito bonita. Daí o velho engraçou-se lá e ficava viajando de uma casa pra outra. Teve duas famílias.

H: Aí, os filhos dele com essa Isabel Torta são os que chamam de Zabel? É isso?

J: É. Zé Zabel, Antônio Zabel e Luís Zabel. Três homens.

$\mathrm{H}$ : E o senhor chegou a conhecer eles vivos - esses três irmãos?

J: Conheci. Conheci dois. O Antônio e o Zé Zabel.

O depoimento de seu João "Padre" é significativo por vários motivos. Primeiro, por ter sido o primeiro e único, em todas as minhas experiências de campo, a oferecer uma versão relativamente coerente para a origem do grupo de cognatos $^{11}$ conhecido como Zabel. Este procederia de uma união consensual extraconjugal de Antônio Alves dos Reis com a negra Isabel "Torta", donde o epíteto Zabel - corruptela e contração de "da Isabel": o José da Isabel e o Antônio da Isabel tornaram-se, assim, Zé Zabel e Antônio Zabel. Seu João "Padre" se refere à mãe do seu pai, Ana Alves de Lima, como a "companheira verdadeira" de Antônio Alves do Reis e à Isabel "Torta" como "contrabanda". Note-se a ocorrência de um arranjo poligínico: "meu avô teve outra família lá", "ficava viajando de uma casa pra outra", "teve duas famílias".

Segundo, pela referência à Isabel como uma "negra velha", "morena", "negrona muito bonita", que morava na lagoa do Tapeba, sugerindo a existência

11 Originalmente (Barretto Filho, 1993), apoiado nas considerações de Bott (1976) sobre redes sociais, tratei tais grupos como de "descendência irrestrita", ou seja, consistindo de todos os descendentes, através de homens e mulheres, de um ancestral comum - uma configuração social característica dos sistemas de parentesco bilateral, caracterizados pela ausência de grupos de parentesco exclusivos, recrutados na base de descendência unilinear. Emprego aqui a noção de cognação, assim, com certa liberalidade para expressar essa relação de parentesco traçada mediante laços genealógicos que vinculam as pessoas a um dado ancestral comum. 
na Caucaia de outrora de processos de hibridação em que entraram não só os povos originários sucessivamente reunidos na aldeia jesuíta de Nossa Senhora dos Prazeres - Potiguara, Tremembé, Cariri e Jucá -, mas também negros forros e/ou fugidos da escravidão e, eventualmente, brancos despossuídos retirantes de secas (como a do "três oito" - 1888 - muito referida em inúmeros depoimentos produzidos em campo). É possível, assim, conceber um multifacetado intercâmbio biocultural, por meio de práticas tais como a adoção, o estabelecimento de vínculos de parentesco fictício (como o compadrio) e os arranjos poligínicos mencionados. O terceiro ponto refere-se ao destino do terreno que Perna-de-Pau possuía - assunto ao qual retornaremos adiante, dada sua importância para a história dos tapebas do Paumirim.

No que concerne a arranjos poligínicos, o próprio Perna-de-Pau teria mantido relação estável e duradoura com duas irmãs: Paulina - ou Maria Deolin(d)a e Tereza "Jacinto" Teixeira de Matos, filhas do velho Antônio Jacinto. Este caso de poliginia sororal é sempre lembrado nas narrativas tapebas sobre Perna-de-Pau e o seu passado recente. Depoimentos registrados em diferentes contextos referem-se de modos distintos, por meio de versões mais ou menos arrojadas, a essa situação.

Em janeiro de 1987, o cacique Alberto, da aldeia Pontes, neto de Perna-de-Pau por parte de mãe, assim se expressou.

Alberto: Sou filho de dois irmãos com duas irmãs. Somos uma nação dada e criada por Deus mesmo.

Henyo: Explica essa história dos dois irmãos casados com as duas irmãs.

A: Porque aí é o seguinte. $O$ avô, que era pai da minha mãe, convivia com duas esposas dentro. Quando estava grávida, estava gestante, estava de neném, uma ia cuidar da outra, está entendendo? Então, somos primos carnais. Não tem pra onde correr. É nação mesmo [...] E naquele tempo a gente só se casava com um da nossa tribo. $\mathrm{E}$ um branco só entrava na nossa tribo se a gente tivesse muita consideração e ele fosse muito respeitador e ele não bancasse covardia. Então, eles podiam entrar na nossa tribo. (Ponte 2, 07/01/1987).

À época, Alberto também mantinha uma relação poligínica com a finada Mocinha e dona Raimunda. Seu pai, Vítor Alves Teixeira, reconhecido como último cacique dos tapebas e enterrado com pompa no dia 3 de outubro de 1984 
- data instituída pela Arquidiocese de Fortaleza e celebrada desde então como Dia dos Tapeba (véspera do dia de São Francisco) - também teve duas mulheres: Alice Araújo Teixeira e Francisca Alves dos Reis - esta sendo filha de Zé Zabel com Paulina e mãe de Alberto. Que Vítor, genro de Perna-de-Pau, seja considerado o último grande cacique, já no contexto da diáspora tapeba (ver quinta seção deste artigo), coloca questões sobre sucessão e herança que, com os dados disponíveis, sou incapaz de responder. Não deixa de ser interessante notar a persistência de arranjos poligínicos, ainda que particulares, nessa linha sucessória.

Naquele mesmo janeiro de 1987, entrevistando a finada Mãe Velha, matriarca de referência nas Pontes, embora não indígena (e três anos depois voltando a entrevistá-la), o número de mulheres com que Perna-de-Pau convivia foi quadruplicado. Um caso extremo, portanto.

Agora a casa do Perna-de-Pau era um salãozão. Começava daqui e ia como pra lá do grupo. Mas era quarto, quarto, quarto. Tinha uns quartinhos, cada qual tinha um quartinho, mas tudo era mulher dele. Ele tinha umas seis pra sete ou oito mulher. Tudo duma família só, né? Não tinha outra pessoa de outro sangue ali. (Mãe Velha, Ponte 1, 12/01/1987).

Oito mulher ele possuía dentro do barracão dele. Cada barracão tinha uma mulher. Tanto que esses filho dele, um é duma mulher, outro é doutra, outro é doutra. São a parte mais é dele, que ele é pai. Mas mãe é separado. É duma, é doutra, é duma, é doutra. Aí, quando eu cheguei lá, menino, aquele quarteirão medonho de casa. (Mãe Velha, Ponte 1, 06/06/1990).

Ainda naquele janeiro de 1987, Zuíla, uma liderança feminina tapeba na aldeia do Trilho de Ferro, explicou para mim o modo como ela percebia Perna-de-Pau e a relação deste com as duas irmãs de sua mãe - ela que se diz, por isso, "sobrinha" do "tio" Zé Perna-de-Pau.

Zuíla: [...] Agora a comida dos tapeba sabe o que é que era? A comida do Zé Perna-de-Pau. Ele passava o dia todinho no mato mais aquelas mulheres. As mulheres dele. O Zé Perna-de-Pau era um homem casado... Ele não era casado; ele era casado só com uma, que era a finada tia Tereza, mas tinha três mulher. Era a finada tia Tereza, a finada tia Paulina e outra por fora que eu nunca sei 
como era o nome da outra mulher dele. Era três. E as três tudo ajudava ele. [...] As outras mulheres que andavam por fora mais ele, tudo ajudava ele [...]. Eu sei que ele era homem de três mulher.

Henyo: A senhora é o que do Perna-de-Pau?

Z: Eu sou sobrinha dele por causa da mamãe, que ele era casado com a irmã da mamãe, a tia Tereza, e junto com a minha tia, a tia Paulina, que era também irmã da mamãe. (Trilho, 14/01/1987).

Dois anos antes, no vídeo documentário Tapeba - resgate e memória de uma tribo, produzido e dirigido em agosto de 1985 por Eusélio Oliveira, quando do início do trabalho assistencial da Equipe de Assessoria às Comunidades Rurais da Arquidiocese de Fortaleza junto aos tapebas, Zuíla se expressou assim:

Era um homem de duas mulheres. Quando a finada tia Tereza estava de resguardo, tia Paulina ia tratar da finada tia Tereza. Quando a tia Tereza saía do resguardo, a tia Paulina ia ficar de resguardo, [aqu]ela ia tratar da outra. Viu? Mas era uma família unida! [...] Por isso é que nós temos essa raça. Essa misturada, é por causa disso aí. É uma misturada grande! Viu?

O depoimento de Zuíla, que nasceu e se criou no Trilho de Ferro, no Paumirim, tem tudo para ser, ao menos em parte, um testemunho ocular. Com 49 anos em 1987, ela pode ter conhecido Perna-de-Pau quando criança. Ela especifica que ele era "casado" com uma e "junto" com outra, distinguindo o caráter das duas uniões, embora nenhuma das quais pareça ilegítima, dado que ele teria convivido com as duas sob o mesmo teto, no mesmo grupo doméstico, e que teriam existido relações de cooperação recíproca entre ambas. O fato novo em seu testemunho é a menção a uma terceira mulher - esta sim, "de fora à parte" -, mas sobre a qual inexistem maiores detalhes. Também chamo a atenção para a noção de "misturada", à qual voltarei a seguir.

Os dados com os quais montei os diagramas (Figuras 2 e 3) com a descendência de Perna-de-Pau não me permitiu localizar nem as três (mencionadas por Zuíla) nem as oito (referidas por Mãe Velha) mulheres de Perna-de-Pau, mas somente as duas irmãs Tereza e Paulina - embora haja menções a Maria Deolin(d)a e Maria Paulina, que penso tratar-se das mesmas pessoas, em função do cruzamento de informações de distintos informantes. 


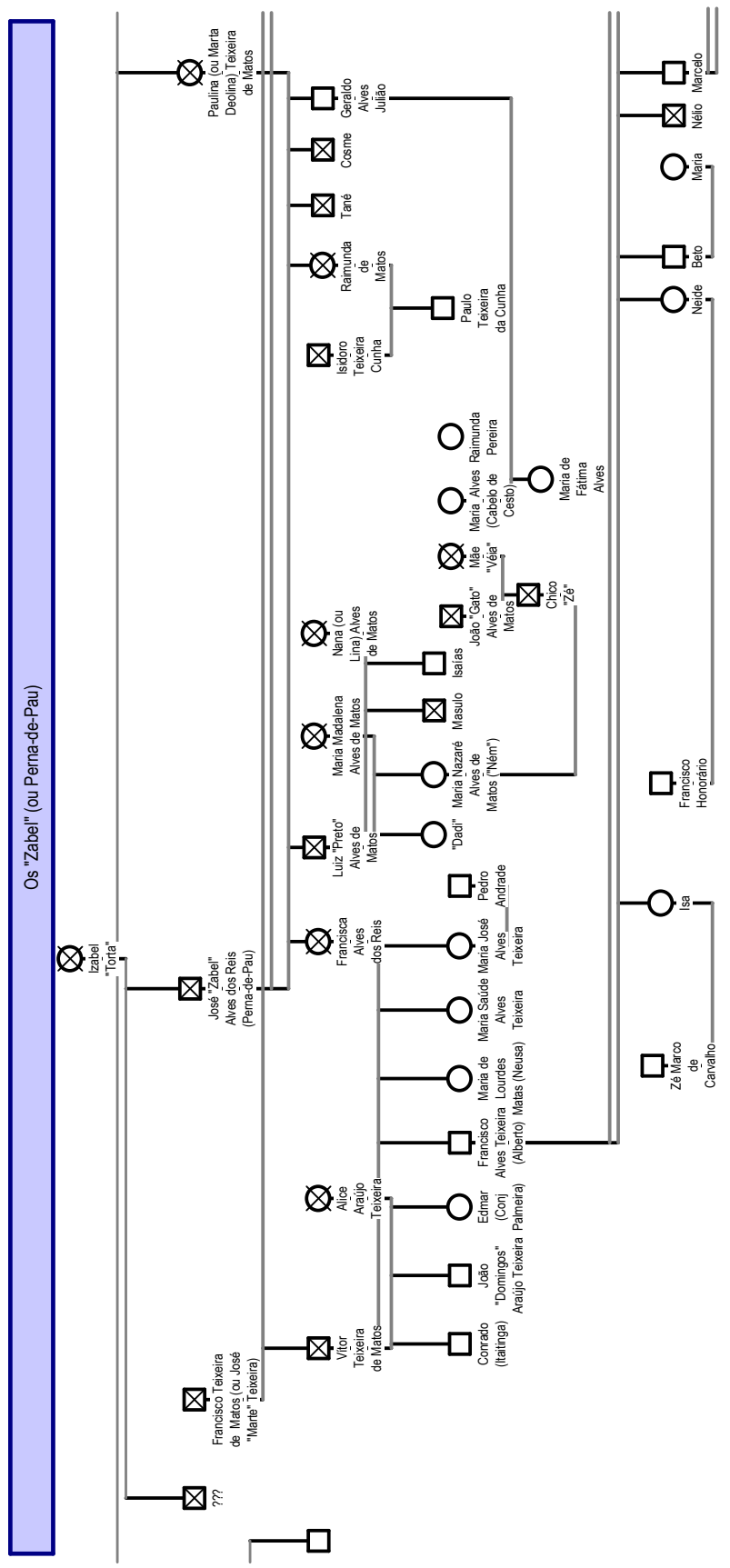

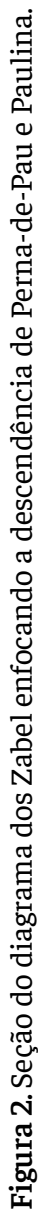




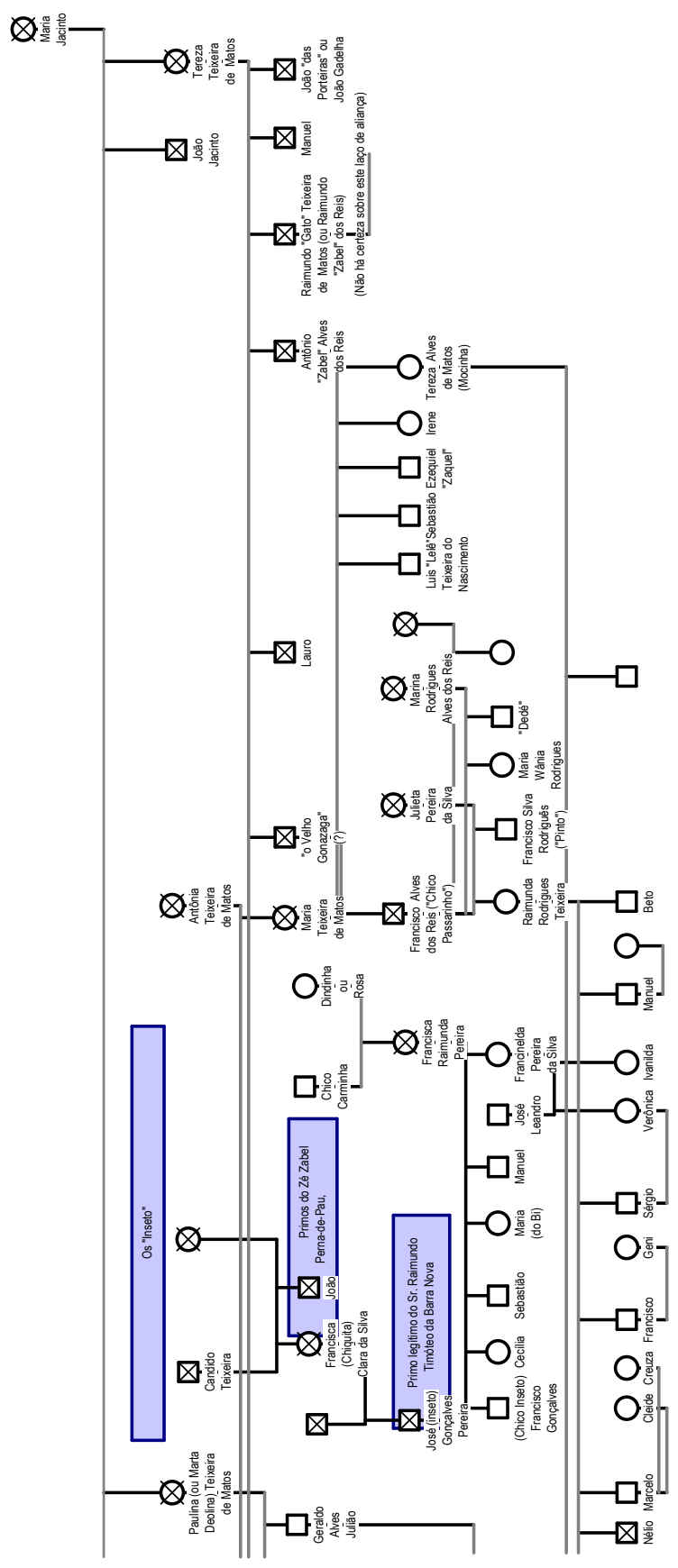

ปี 
Se a variação no número de mulheres pode ser creditada à imaginação das depoentes, nos depoimentos destas e no do cacique Alberto emergem elementos que me parecem fundamentais: a interpretação, compartilhada por tapebas e não índios (e ideologicamente mais articulada e marcada por alguns cognatos de Perna-de-Pau), de que os tapebas são uma "nação", uma "raça", uma "família unida", originária desse caso de poliginia sororal; e a centralidade da figura e da liderança de Perna-de-Pau no Paumirim.

Tal união sororal poligínica gerou descendentes, alguns dos quais casaram-se entre si e/ou com primos da "família (de) Jacinto" e outras, constituindo uma descendência peculiar (ver Figuras 2 e 3). Tomar-se-ia parte na "família (de) Zabel" porque se descenderia de Perna-de-Pau: "São a parte mais é dele, que ele é pai. Mas mãe é separado" - como disse Mãe Velha.

Como já explanei alhures, os tapebas empregam ubiquamente o termo "família" ligado à adscrição tapeba, formando as expressões "família tapeba", ou "família de tapeba". Isso remete ao vínculo social estreito desse coletivo e ao sentimento subjetivo afetivo e tradicional de constituírem um todo. Os tapebas também costumam se expressar dizendo que as famílias "Zabel" (Alves dos Reis, Alves Teixeira), "Coco" (Alves de Matos, Teixeira de Matos), Jacinto, "Grande" (Jerônimo do Nascimento), "Milunga", "Carnaúba", Guimarães e "Macaco" (Paiva) $^{12}$ são tapebas, ou da família de tapeba. Essas "famílias" da "família de tapeba" constituem distintos grupos de cognatos, por meio dos quais é possível reconhecer a ascendência de uma pessoa como tapeba.

É tudo uma comandita só. É tudo uma misturada só: tudo irmão, primo, prima. Tudo tio, tia. É essa arrumação aí, dessa família se casando assim. (Zuíla, 49 anos, Trilho, janeiro de 1987).

Bem, agora já estão misturados. Já tem eu que não sou da família, já estou no meio. E tem mais. Antigamente era só eles mesmo: era primo com primo, irmão com irmão, era tudo, era uma família só. Não entrava ninguém. Porque se

12 Tendo usado aspas até aqui para destacar as alcunhas que viram nomes de famílias, ou seja, referências a distintos grupos de cognatos, deixo de usá-las doravante em benefício da clareza do texto. 
entrasse tinha que brigar. Agora tão manso, mas eram valentes os tapeba. (Antônio “Potinho", Trilho/Paumirim, 18/01/1987).

[Pergunta: Quer dizer, então, que esse pessoal da família de Jacinto não é Tapeba?] Não. Se é hoje é pela seguinte maneira, assim que nem eu sou. Porque Jacinto casou na família [...]. Agora, como a família foi multiplicando, hoje já tem tapeba casado na família de Jacinto, tem Jacinto casado na família tapeba. Tem Coco casado na família de tapeba, tem Jacinto casado na família de Coco. Então, é isso. Tem uma misturada. É um bolo mais horrível do mundo. (Chico Bento, 55 anos, Vila Nova, junho de 1990).

Notei que as uniões poligínicas e o casar-se em família suscitavam sentimentos ambivalentes entre os tapebas contemporâneos. Isso porque se, por um lado, partilham dos sistemas de valores da sociedade regional em que a monogamia é regra, por outro, reconhecem nessas condutas um claro indicador de sua ancestralidade indígena, uma prática tradicional dos "troncos velhos" que faz da "família tapeba" uma "misturada" difícil de deslindar. Embora vigore uma representação em torno de "casar em família" como uma prática "correta" e "tradicional", eram e são livres as uniões formais e consensuais entre tapebas e não índios ("gente de fora", "outras famílias").

É aqui que a noção de "misturada", usualmente associada à "família de tapeba", assume importante e duplo significado. Ela é atualizada para referir-se, de um lado, à prática de se "casar na família" e, de outro, à liberdade de união com gente de "outra família", "gente de fora", "outro sangue", "outra raça". A isso se associa a ideia de que a família é muito grande e encontra-se muito espalhada. "A nossa família já vai longe. Tem tapeba no Rio, na Brasília, no São Paulo." A noção de "misturada", assim, indica a dificuldade (e até a impossibilidade para alguns) de "destrinchar toda a família", devido às múltiplas direções que as uniões tomaram e à mobilidade ligada às estratégias de reprodução social. Por isso tudo, o termo "misturada" também pode assumir conotações pejorativas, sugerindo relações incestuosas.

É tentador, assim, aludir ao Paumirim como um grupo local endogâmico, com casas tipicamente indígenas, uma das quais - a do cacique Perna-de-Pau - teria sido um tipo de residência coletiva. Não obstante, certamente foi um território habitado por uma população local distinta, em que dificilmente se 
admitia gente "de fora da família" - como veremos em outros testemunhos a seguir -, em que Perna-de-Pau teria exercido sua liderança, sendo tido como o "último tuxaua", após cuja morte - ocorrida, estimo, em meados do século XX - os tapebas que viviam sob sua liderança saíram em diáspora para formar as muitas comunidades em que vivem hoje - como discorrerei a seguir.

Importa notar que toda essa sintaxe do parentesco é atravessada por uma disputa pela autoridade e legitimidade de se falar sobre os tapebas e o passado destes, principalmente entre os Zabel, que se julgavam os legítimos interlocutores para isso. Não eram incomuns as tentativas de desqualificar discursos de outros parentes com base em argumentos, por exemplo, de que a pessoa não havia sido criada "no meio deles", ou de que a pessoa sequer seria tapeba. Essa disputa pela autoridade e legitimidade era constante, e contaminou inclusive o debate público sobre se os tapebas são ou não índios, no contexto do conflituoso procedimento de demarcação da terra indígena, que se arrasta há 35 anos. ${ }^{13}$

\section{Zé Zabel: a perna de pau, a autoridade e o estilo de liderança}

A alcunha Perna-de-Pau - que já operou, também, como uma categoria de adscrição no cenário local ("os pernas-de-pau") - advém do fato de o finado José Alves dos Reis ter uma perna-de-pau - segundo consta, uma prótese confeccionada pelo próprio para substituir um pedaço de uma de suas pernas, perdido num acidente. Como não podia deixar de ser, num caso como esse, há

13 A ex-deputada estadual e candidata derrotada às eleições para a Prefeitura de Caucaia em 1988, Maria Lúcia Correia (PMDB), nora do tenente-coronel Edson da Mota Correia (ver próxima seção), ao negar que os tapebas fossem índios, fez a seguinte declaração pública no jornal de maior circulação do estado do Ceará: "O que existe é um grupo descendente de um caboclo conhecido pela alcunha de 'Perna-de-Pau' que habitou na área de Caucaia no início do século e que teria vivido maritalmente com duas irmãs, o que gerou um grupo racial fechado, que foi habitar nas proximidades da Lagoa do Babaçu [Pabussú?], na estrada da localidade de Garrote, a Oeste da sede da antiga Soure, hoje Caucaia" (Maria Lúcia..., 1987). A matéria prossegue informando que uma bisneta de Perna-de-Pau teria sido criada na residência do tenente Edson, seu sogro, e que a deputada acreditava haver muita "fantasia" no que se referia aos hábitos daquela gente. Curioso notar, portanto, como a história de Perna-de-Pau e dos Zabel era conhecida além das fronteiras do grupo por membros da elite política local - que, nesse caso, a usam para tentar descaracterizar o pleito do grupo de ser reconhecido como indígena. 
várias versões correntes sobre o modo como ele perdeu a perna. Uma atribui a perda da perna a um acidente na linha de ferro, pois era comum eles voltarem embriagados para casa ao final de um dia de pescaria, ou de venda de produtos na cidade, estado no qual muitos morreram e se acidentaram, abalroados pelo trem. Outra, que teria sido durante a construção de uma casa, no Trilho. Uma terceira versão, mais corrente que as demais, é que ele teria perdido a perna em um acidente com um rojão - ou uma explosão retardada de uma ronqueira nas festas juninas.

O finado Geraldo Alves Julião, o Geraldão da Vila Nova, era um dos dois últimos filhos vivos do finado Zé Zabel Perna-de-Pau no final do século XX. O outro era João das Porteiras, uma localidade no pé da serra do Juá, que eu só vim a conhecer anos mais tarde durantes os estudos de identificação da TI Tapeba. Tido pelos tapebas como uma pessoa esquiva, grossa, carrancuda e mal-educada, só consegui conversar com ele duas vezes, uma em cada período de campo da pesquisa de mestrado. Da primeira vez, em janeiro de 1987, logrei produzir uma importante entrevista com ele na qual se referiu ao incidente que mutilou seu pai.

Geraldão: Ele festejando uma festa de São João [...]. No Trilho. Aí, foi na última noite de festa que é tirando o terço. Aí ele fazia... A arma era um cano dessa grossura assim, entupido de barro e cheio de pólvora, né? [...]. Era um no começo e outro no fim, que era pra detonar, não sabe? Aquele tiro danado, pra saber que estava festejando. Aí, ele tocou fogo, aí não detonou, né? A ronqueira entupiu, que era um cano dessa grossura assim, enfiado em dois tornos de pau [...]. Aí ele foi escavacar o ouvido da bicha com as pernas do lado do cano, né? Taboco! Aí pipocou de vez. Pou! Aí, arrancou a perna dele, cortou a perna dele assim. Esbagaçou. Aí ficou só esse negócio assim que volta assim pra trás.

Chico Pedro: O cotovelo do joelho, não é isso?

G: É. Aí ficou. Foi pra cidade, mandou cortar. Os doutores cortaram ela, ficou. Sarou, ficou bom. Aí ele mesmo inventou lá uma perna de pau [...]. Cortou um pedaço de pau grosso, aí passou a enxó pra cima [...]. Aí, tirou de um lado e outro, fez aquele buracão. Acabou que fez dois buracos aqui, porque ficou a tabuleta, né? Daqui pra cá ficou a tabuleta e ele meteu uma corda assim, amarrava na cintura e meteu o pé dentro e forrou de pano. Aí, meteu o pé. Aí andava pra todo canto com aquela perna dele. (Vila Nova, 11/01/1987). 
A força e autoridade de Perna-de-Pau parecia decorrer de vários atributos: sua aparência física, seus hábitos e habilidades, sua capacidade de convocação, a posse que detinha de uma área herdada dos seus pais e depois perdida em transações espúrias (ver quinta seção), e as relações ambivalentes que manteve com pessoas da elite política local (como veremos a seguir nesta seção). Imagine-se um velho cafuzo alto, forte, encorpado, barbudo, feio, com uma perna-de-pau e um chicote na mão, fumando cachimbo, sanfoneiro, que gostasse de cachaça, de temperamento forte e invocado.

Antigamente, nós era muito criança, nós andava mais esse velhinho, mais ele, pedindo esmola nas casas, de porta em porta, pedindo esmola nas casa. Nós chegava naquelas portas, pedia aquelas esmolas, aí aquele pessoal ricaço dava esmola a ele e chamava ele de "Papai Noel" [...], aí quando as criança viam ele, diziam: “Lá se vem o Papai Noel! Lá vem o Papai Noel!” (Zuíla, no vídeo documentário Tapeba - resgate e memória de uma tribo, agosto de 1985).

Agora ele tinha uma perna-de-pau, uma perna mermo, só uma. A outra era boa. Ele andava com uma chibata desse tamanho na mão. Muito feio, ele. Era um velhão barbado, feio mermo, viu? [...] De longe eu via a tocha de fogo, ele fumando aquele cachimbão. [...] Ele era a formatura de um velhão mesmo, ele era feio mesmo, né? Eu nunca corri com medo dele, não [...], e valente. (Domingos Flor, casado com uma tapeba, Trilho/Paumirim, 16/01/1987).

O compadre Antônio [Zabel] era, assim, um molecotezinho, mas os braços dessa grossura as pernas grossas também. Muita força. Seu Zé pegava nós assim pela cintura - nós era desse tamanho, dessa grossura, mal feitos que só - pegava nós assim, jogava nós assim pra cima e aparava. Minha mãe: "Seu Zé o senhor não mate as minhas meninas." "Eu, nada..." Eles dois era desse jeito. O filho e o pai. (Dona Lúcia, comadre de um tapeba, Capoeira, 19/05/1990).

Perna-de-Pau. É. Eu conheci ele já com aquela perna de pau. Era tocador de harmônica. Nunca sei quem levou uma surra aí um dia. Foi! [risos]. Era positivo. Se ele pegasse um pelas brechas, estava seguro. Era o Perna-de-Pau. (Seu Avelino, Trilho/Capuan, 25/04/1990). 
Além dos depoimentos já citados, inúmeros outros corroboram a existência de algum tipo de estrutura de autoridade e respeito legitimada pelos tapebas, principalmente em relação aos mais velhos, os das gerações do finado Perna-de-Pau e de seus filhos.

Dona Raimunda, uma das mulheres do já referido cacique Alberto, ao final dos anos 1980 já convivia com os tapebas há cerca de 40 anos, desde que sua mãe se juntou com Chico Passarinho, sobrinho do Perna-de-Pau. Tendo vindo de Aracati porque seu marido a havia deixado, a mãe de dona Raimunda buscou o auxílio de uma tia no bairro de São Geraldo em Fortaleza, que a recomendou para tomar conta de um sítio de um compadre no Capuan. Dona Raimunda relatou assim esse primeiro encontro com os tapebas.

Raimunda: Aí nós ficamos no Capuan. Aí o Chico Passarinho, vendendo passarinho, sabe? Corrupião, essas coisas. Começou a se engraçar pela minha mãe. Aí foi e perguntou se a minha mãe queria morar mais ele. Aí ela foi e disse: "Não dá certo, não. Você é muito novinho." Que ele era bem novinho, ele tinha 16 anos. [...] Ela disse: "Não dá certo, não." Ele foi e disse: "Dá. Mas só é que você não vai ficar aqui. Vou levar você pra minha aldeia." Ela fez: "Aldeia?!" Ela ficou com medo, sabe: "Esse negócio de aldeia, chega lá o pessoal vão brigar." Ele disse: "Não, briga não." Aí nós fomos morar no Trilho, lá onde hoje em dia é o lado da casa do irmão da Zuíla. Que a casa do velho avô do Alberto era pro lado de lá, sabe? Aí, nós fomos morar lá. Aí, quando nós chegamos lá, aí o velho foi e disse que não queria ele com a minha mãe. "Você arrumou essa mulher aonde? Essa mulher velha, amarela desse jeito?” Que a minha mãe era bem alva, bem branquinha.

Henyo: $\mathrm{O}$ velho, quem?

R: O velho pai do Chico Passarinho. O velho Gonzaga, que não queria. Que o velho Gonzaga era irmão da mãe do Alberto, filho do velho Perna-de-Pau, entendeu? Que era dos mais velhos, por isso disse que não queria. Aí, minha mãe disse: "Pronto. Agora vou-me embora." Ele disse: "Não, meu pai. Deixa ela ficar mais eu? Eu me agradei dela e ela vai ficar mais eu." Ele disse: "Mas não tem ninguém branco no nosso meio!" - o velho, sabe? Não tinha ninguém branco. Eu acho que quem inventou esse negócio de se misturar aos brancos foi o Chico Passarinho, né? Porque levou minha mãe pro meio deles. Acho que foi. Aí, nós ficamos morando lá, aí eu fui crescendo no meio deles. (Ponte 2, 02/06/1990). 
Voltemos ao Geraldão da Vila Nova, que se mostrou reticente em dar continuidade ao seu depoimento, quando derivamos para tratar da liderança de Perna-de-Pau. Na ocasião, fiz-me acompanhar pelo finado Chico Pedro, então, uma jovem liderança das Pontes, que chama Geraldão de "tio".

Chico Pedro: E aí no Trilho, aonde o tio morava, que o senhor contou pra mim. Soldado quando chegava lá, na época do Perna-de-Pau, nesse tempo. Soldado quando chegava lá, ele era expulsado a pique de quê?

Geraldão: Ah, mas isso aí não adianta ninguém dizer, não, porque às vezes... Pode não... [...]

CP: Como era antigamente que a gente sobrevivia, né? Em cima do corte ali aonde mora a Zuíla. Tudo bem, não tem problema não. Pode contar. [...]

G: Lá era o seguinte. Cof! Cof! Lá, quando o meu pai era vivo, debaixo dos cajueiros onde a gente morava e da casa. Porque lá era umas quintas de cajueiro. Aí ele, não tinha polícia que entrasse lá dentro pra ir buscar um filho dele. Não levava, não. Porque o velho dava um grito e polícia nenhuma entrava lá dentro pra levar, não. Porque nesse antigamente era o... Que ele dizia que a polícia não levava porque ele entrava na Caucaia e resolvia tudinho cum os compadres dele, né? Nesse tempo tinha o... O delegado era o... E era uns tudo maior, queriam invadir lá pra ir buscar a gente preso, açoitava. Aí, nessa altura ele não deixava, né?

Henyo: Mas por algum motivo iam levar gente presa?

G: Não, sem motivo nenhum. Só porque o pessoal bebia cachaça, né? Bebia cachaça e eles queriam invadir, pra modo de buscar o pessoal, açoitar, isso e aquilo outro. Aí, ele não deixava. Não deixava a polícia invadir sem a lei. Aí ele ia... Quando ele passava pela rua de Caucaia, que nós cansamos de chegar lá mermo dentro da Caucaia, ele ia vender os feixes de lenha dele, com o pessoal dele, a família dele. Ele dizia lá ao tenente Edson, dizia assim: “Cumpadi, quando eu der um grito aqui dentro da Caucaia, pode esperançar que aqui é o Perna-de-Pau." [...] O meu pai era diferente de nós. Depois dele dar um grito dentro da aldeia dele, que ninguém encostasse. (Vila Nova, 11/01/1987).

Notem-se as referências ao "grito" de Zé Zabel Perna-de-Pau, à "aldeia dele" e à autoridade que ele exercia no local, se impondo inclusive às forças de segurança pública, em função das relações sociais que ele agenciava por meio do compadrio. A menção específica ao tenente Edson Correia como sendo 
compadre do Perna-de-Pau é extremamente significativa e reapareceu numa longa entrevista realizada três anos mais tarde com Francisco Bento de Souza, o Chico Bento, então com 55 anos, e sua esposa Raimunda Francisca da Silva de Souza, a Mundola, então com 47 anos - esta irmã de Zuíla.

Chico Bento: Os tapebas, se eles andassem assim num lugar aonde esse pessoal que nem o doutor Otto, esse pessoal que justamente se considera como rico, se eles pisassem ou andassem na fazenda deles, eles proibiam. Eles proibiam deles andarem nas fazendas deles. Porque eles eram um pessoal que não ligava a vida, né? Se fosse preciso, se eles - por exemplo - achassem uma coisa fácil, eles levavam, seja lá de quem quer que fosse. Se achassem uma coisa fácil, eles levavam. Eles cortavam arame, saltavam cerca e faziam buraco na cerca, era assim. O caminho deles era direto. Se eles viessem no caminho e pretendessem de passar, eles cortavam o arame de quem quer que seja [...]. E ia-se embora a viagem dele. Entonce, todo esse pessoal eles prendiam tudo. "Quem foi que passou aqui?" "Foi os tapeba." Aí eles iam e prendiam os tapeba. Metia na cadeia e prendia. Aqui tinha o finado tenente Edson, que quando sabia que tinha algum tapeba preso, aí mandava soltar os tapeba. Até que teve uma vez que a polícia de Caucaia prendeu o finado Luís "Preto", o finado Vítor e o finado Toné [filhos e genro, o segundo, de Perna-de-Pau].

Henyo: Por causa de quê?

CB: Por causa de bebedeira, por causa de cachaça. Por qualquer coisinha os homem mandava prender. Ou esses Pontes mandava prender, ou os Sales mandava prender, ou o velho Zé Florindo mandava prender, ou aqui o pessoal do velho Milton Firmeza mandava prender. Era assim, qualquer coisinha os tapeba estava preso. Entonce, o tenente Edson era só o que soltava, era somente quem soltava os tapeba.

H: Por que ele soltava?

CB: [...] É que o tenente Edson conhece todo esses tapeba a fundo, conhecia os mais velhos e todos eles. $\mathrm{O}$ tenente Edson tinha uma grande amizade com eles porque conheceu eles sempre aqui, vivendo aqui mermo dentro de Caucaia. [...] E o tenente Edson não negou a parte, que eles eram índios.

Também em 1990, produzi um testemunho revelador com dona Lúcia Estevão Silva, então com 58 anos, natural do Cabatã, bairro de Caucaia, e moradora da 
Capoeira desde 1981. Ela era responsável pelo setor de terras e projetos da Associação dos Moradores do Bairro Pe. Júlio Maria, fazendo parte da diretoria desta, e teve um relacionamento estreito e pessoal com os tapebas na sua infância. Segundo seu testemunho, o finado Zé Zabel Perna-de-Pau trabalhou no terreno de sua mãe, limpando o quintal e reparando a cerca do curral que ela arrendava para os donos de rebanho para a engorda antes do abate. Dona Lúcia era madrinha de batismo de um filho do finado Antônio Zabel, não o irmão, mas o filho de Perna-de-Pau de quem ela ficou amiga ainda molecote, tendo sido madrinha quando tinha seus 17 para 18 anos. Podemos situar, assim, em torno de 1950 o ano em que dona Lúcia se tornou madrinha de Sebastião, que findou sendo criado por padres, em virtude da morte de sua mãe. Num rico testemunho sobre o relacionamento de sua família com os tapebas, em especial Zé Zabel e seu filho Antônio Zabel, dona Lúcia se expressou assim em dado momento:

E tinha mais uma coisa: quando havia questão aí no meio deles, ele mesmo era quem decidia. Eles... Aqui não tinha policiamento nem nada. Ele acalmava as coisas e ia lá no tenente Edson. Aí, dizia o que tinha ocorrido. O tenente era o homem de Caucaia, outrora. Era quem mandava em Caucaia. Aí bastava ele chegar lá e contar: "Olha, tenente. Houve isso, isso, assim, assim lá." Então pronto, ele acalmava tudo. Se fosse difícil de ir pro hospital levar, [o tenente Edson] levava pro hospital; se não fosse, eles mesmo levavam. (Capoeira, 19/05/1990).

Assim sendo, neste esboço de biografia social do Perna-de-Pau, é importante abrir um parêntese para resumir a biografia do tenente-coronel Edson da Mota Correia, tal como logrei identificar em fontes documentais (Sampaio; Costa, 1972) - ele que dá nome a uma das principais vias que atravessa o município de Caucaia de leste a oeste: a BR-222 antigo traçado, quando entra no perímetro urbano da cidade sede do município, ganha o nome de Avenida Coronel Correia.

Filho do "coronel" Antônio José Correia e de Ana Ernestina da Mota, Edson da Mota Correia foi subcomandante da polícia, oficial do exército, tenente, "revolucionário" de 1930. Nomeado prefeito de Aracati em 1931 pelo interventor Carneiro de Mendonça, e, em seguida, delegado do governo junto a várias prefeituras, entre elas Caucaia, foi posteriormente escolhido para a chefia da Casa Militar do interventor Moreira Lima. Em 1934 foi eleito deputado à Assembleia Legislativa. Só depois é que foi promovido a tenente-coronel e 
nomeado subcomandante da polícia. Reeleito ininterruptamente desde 1950 até sua morte em 1985 a uma cadeira na Assembleia Legislativa Estadual, Edson Correia era tido como um dos mais tradicionais políticos cearenses, detendo durante muito tempo a liderança eleitoral de Caucaia, somando nove legislaturas. Arenista, esse ex-diretor do Departamento de Secas e ex-presidente da Assembleia Legislativa - onde chegou a ocupar a chefia do governo em quatro oportunidades, em substituições interinas - parece ter manipulado importantes recursos sociais e entrou para a história do município pelo modo extremamente violento como fazia política. É comum ouvir relatos sobre a atuação dele que fazem referência às violências, intimidações e atrocidades por ele cometidas, ou a mando dele. Em alguns desses relatos ele aparece como um antagonista - "inimigo" - dos tapebas e de suas aspirações.

Os testemunhos de Geraldão, Chico Bento e dona Lúcia diferem desses relatos nas menções que fazem a Perna-de-Pau e ao tenente Edson como compadres; e que este reconhecia a imemorialidade da presença dos tapebas como índios no município. Em função disso, ele teria sempre interferido em favor dos tapebas junto à polícia local - tendo em vista sua biografia, marcada por uma ascensão hierárquica dentro do estamento policial militar.

Qual, portanto, a fonte e o fundamento da autoridade exercida por Perna-de-Pau? Como vimos, os testemunhos dão conta de que em caso de brigas, agressões e até mesmo morte, nem mesmo a polícia se metia, pois eles lá "se resolviam entre eles". Perna-de-Pau seria quem legislaria e julgaria as questões surgidas no âmbito da convivência entre eles. Fica-se com a nítida impressão de que teriam existido mecanismos reguladores e de sanção internos ao próprio grupo, legitimados por este como aptos a resolver os conflitos. Os testemunhos indicam que tal autoridade seria tanto fruto de uma tradição autóctone quanto assentada numa relação (pessoal, de compadrio, ou outra) entre o "indio velho" e o tenente Edson, e outros compadres e amigos influentes.

Henyo: Agora, a senhora falou que, lá dentro, ele é quem resolvia as questões...

Lúcia: É. Pois é, assim. A aldeia era assim. Eles era tudo num local só. Aí quando havia assim... Porque às vezes havia uma cacetada. Porque esse tempo ninguém brigava nem de faca, nem de bala. Isso era difícil. Era mais de cacete. Aí quando havia isso, ele ia lá acalmar aquele povo. Mas se caso fosse preciso ficar muito doente, aí ele falava... Quando ele voltava... Polícia não ia lá. Ele é quem olhava 
tudo, agia tudo e aí ia lá no tenente e contava tudo ao tenente, e se precisasse prender, o tenente ia lá buscar e se não precisasse ficava só ele, resolvia tudo mesmo por lá. Às vezes, no meio deles mermo, não precisava prender. Às vezes era por causa de bebida. Eles chegavam meio bêbados e se estranhavam um com outro, aí pronto. Mas ele era o chefe de todos. (Capoeira, 19/05/1990).

A natureza deles era a natureza que eles mesmo brigavam, que eles mesmo só faltavam beber o sangue um do outro. E brigavam, brigavam e no outro dia estavam bem. Se rachava a cabeça de um, lavava com água de sal, com cachaça, pronto. Não ia pro doutor, não ia pra nada. Se levasse um tiro, uma facada, deles mesmo, por lá, não ia procurar delegacia, não. Eles nunca procuraram delegacia da parte de ninguém. A parte era deles mesmo. (Mãe Velha, Ponte 1, 06/06/1990).

Aí, não tinha quem fosse bulir com o pessoal de tapeba, não. Porque quando chegava lá, já viu: o marechal do lugar era ele, viu? A ordem que ele dava estava certa. Porque não tinha uma autoridade que fosse se meter lá no negócio dele. Não tinha quem visse tapeba ir preso, não senhor. Lá?! No tempo que o Zé Perna-de-Pau era vivo, o cacique velho, lá tinha respeito! (Zuíla, no vídeo documentário Tapeba - resgate e memória de uma tribo, agosto de 1985).

[...] E quem era o protetor desse Trilho de Ferro aqui era o Zé Perna-de-Pau. O Zé Perna-de-Pau era quem mandava em tudo. Polícia não mandava nada aqui. Que a ordem que ele desse estava certa. Quando ele gritava, não tinha polícia que se metesse aqui. Era ele mesmo. O índio mesmo, o índio velho. Era o cacique velho do Trilho de Ferro era o Perna-de-Pau. (Zuíla, Trilho, 14/01/1987).

\section{A "convivência" de Perna-de-Pau e dos tapebas}

A figura de Zé Zabel Perna-de-Pau também epitomiza certo estilo e ritmo de vida, a que os tapebas e os regionais chamam "convivência", vista por todos como peculiar, em que algumas atividades - como a pesca no mangue e o extrativismo vegetal e animal - aparecem como centrais. Note-se que, nos depoimentos, a presença dele ali no Paumirim, no Corte, no Trilho de Ferro, sempre aparece ligada a certas práticas e a um estilo de vida, bem como a uma 
paisagem local, tidos como característicos e emblemáticos de um momento de maior proximidade social e de redes com conexidade mais intensa entre os tapebas.

Antigamente, nós era muito criança, nós andava mais esse velhinho, mais ele, pedindo esmola nas casas, de porta em porta [...] Aí, quando a gente passava aquela semana naqueles negócios de esmola, ai é que ele dizia assim - as esmola não dava pra gente passar mermo. Aí ele dizia assim: “Minha filha, amanhã nós não vamos pra negócio de esmola, não. Amanhã nós vamos pro mato tirar croatá pra nós fazer pelinho pra nós vender aqui. Umas cabeça-de-nego, umas japecanga, umas contraerva, relame branco - essas coisas - pra nós trazer pra nós vim pra cá pra venda, né, minha filha?” Eu dizia: “É sim senhor." Era eu, o tio José, o finado Cosme, um rapazinho que ele tinha, nós andava junto. [...] Aí quando nós ia vender os bicho, as coisas que nós ia vender, ele arrumava aquelas bolsa de dinheiro, de comida, [...] pão, [...] tripa de gato, essas coisa assim ele trazia pra gente comer. Chegava, era aquela ruma de gente tudo na beira da linha mais nós, lá nas cabaninha de palha, comia junto mais nós, as panela cheia. Ali era pra todo mundo que chegava. Quando acabava daquelas comidas... O velho tomava muito álcool sabe? [...] Aí começava aquelas festas, não sabe? Aí batia um negócio de pandeiro, era colher, aqueles couro de gato, fazia aqueles tambor, fazia aquelas coisa. Aí começava a dançaria daquele pessoal todo, aquelas brincadeiras, viu? Ali, era noite a todinha ali. [...] Aí, quando era festa de reisado, aí ele fazia aquele boi muito bacana, viu? Ali eu vou te contar, como era lindo, viu?! Ali aquelas catirina tudo bacana, aqueles prevelé, aquelas burrinhas, aquelas coisas, a coisa mais linda do mundo! Viu? [...] Os acompanhamentos deles era negócio de coisa, era batendo na lata, era triângulo, era realejo, essas coisas assim, não sabe? [...] Mas era só aquelas casinha pequenininha, tudo aquelas cabaninha de palha, era mais cabaninha mermo. Era as paredes tapadas assim de folha do mato, viu? [...] Ali ninguém tinha remédio de médico. Ali remédio era do mato. Se uma criança estava com dor de cabeça, fazia um remédio daqui dacolá, dava àquelas crianças pra tomar. Era aquela coisa assim, viu? Nós comia uruá, nós comia negócio de gado morto, que davam pra nós. Nesse tempo nada valia nada. Morria às vezes uma vaca de parto, dava a nós pra nós comer. Os nossos pais juntavam, trazia pra casa. Nós comia aquelas vaca velha morta, viu? [...] Aí nós ia, trazia aquele horror de carne. Aí salgava e ficava comendo aquilo ali, não sabe? 
[...] Vestia vestido de saco! [...] Nós dava graças a Deus quando a mãe comprava um saco que cortava o pescoço e era só costurando assim de banda e nós se socava dentro. (Zuíla, no vídeo documentário Tapeba - resgate e memória de uma tribo, agosto de 1985).

Meu marido mesmo, chamado Pretinho. Aí eu ouvia aqueles toques de mão, "tuc, tuc, tuc". "Pretinho, que zoada é aquela?" "Minha velha, aí é a mata dos tapebas, dos índios." Eu dizia, "Que índio?” “Os tapebas! Você quando chega do mercado não vê aquele bando de negro comprando aquelas coisas ali?" Tudo era freguês dele, sabe? [...] Aí ele foi, matava gado lá do seu Alfredo [Miranda] e a gente só ouvia aquela zoada de manhã. Eu dizia: "Deixe estar que um dia eu ainda vou espiar." Na vila só encosta só eles mesmo. Não entra ninguém, mas parece que meu sangue deu com eles, sabe? [...] Ah, o Perna-de-Pau não fez questão nenhuma de nós duas. A Zezé preta da cor de panela. [...] Aí, quando cheguei lá, aquele quarteirão medonho de casa. As camas tudo feita de pau. [...] Não tinha rede. Eles não dormia em rede. [...] Eles não andava de ônibus, não. Andava de trem, mas pra ir pra cidade vender essas coisa eles iam a pé. Eles nunca trabalharam a ninguém. A nenhum. Aqueles tapeba dacolá. [...] Era, tudinho era assim. O Perna-de-Pau tinha uma sanfona desse tamanho. E tocava. E um batia num triângulo. (Mãe Velha, Ponte 1, 06/06/1990).

Isso aqui eles tiravam croatá, armavam aquelas gaiolas pra pegar gato, raposa, cobra e qualquer bicho. $\mathrm{O}$ que desse certo eles pegavam, levavam pra cidade e vendiam. Vendiam e quando vinham já se sabia: trazia a garrafa de cana. Agora, tem uma coisa: dão valor à cana. [...] Aí vinha o peixe, vinha a carne, vinha tudo. A feirinha da casa. Bem, a convivência deles era essa. E pescando. Iam pescar na maré, quando vinham, vinha o peixe, vinha o camarão, vinha o aratu, vinha o dinheiro, vinha tudo. Viviam só disso mermo. Eles nunca trabalharam, sob esse ponto aí... Só uma parte dos tronco velho é que não deixava de plantar os roçadinhos deles [...]. Pegavam cobra, vendiam. Outro deles aí fazia louça, vendia. [...] Por aqui eles entravam, subiam nesses pés de pau, botavam o visgo pra pegar os passarinhos pra vender, levarem pras ruas. Quando vinham, traziam aquele dinheirinho. Comprava um feijãozinho, compravam o arroz, compravam a carne, o peixe e aí alimentavam os filhos. (Antônio "Potinho", Trilho/Paumirim, 18/01/1987). 
A vida dele era só pescando, né? Era pescando, trabalhando de jardineiro. Lá pros matos arrancar croatá pra tirar o pelo pra vender na cidade, né? Então, quando ele vinha de lá pra cá, trazia tudo que era necessário pros filhos. O nosso conviver era esse. Aí quando era bem cedinho nós ia voltar pro mangue, de novo, pescar. De tarde ia pra casa. Assim era todo santo dia. Nosso trabalho era esse. Que eu me lembre. (Geraldão, Vila Nova, 11/01/1987).

A convivência deles era o seguinte. Eles viviam de pesca, viviam pescando. Quando arranjavam trabalho eles trabalhavam. Ele [Perna-de-Pau] era muito trabalhador. E também quando morria um bicho na linha eles corriam, porque eles não tinham como, né? Tratavam de tirar o couro do bicho e comer. Comiam tudo. Comiam cobra, essa cobra grossa preta. Cobra-de-veado. [...] Aí eles bebiam muito e eu não sei se a morte dele foi bebida ou se foi raiva. Não sei. Eu sei que ele bebia muito. Mas ele vivia de pesca. Ele pescava, eles pegavam passarinho. Todo passarinho eles sabiam assoviar e pegavam. Fazia aqueles visgos. Hoje é que ninguém vê mais eles pegando passarinho. E levava pra feira da cidade. Lá eles faziam aquelas vendas e quando voltavam traziam... Quando era na lua cheia de janeiro, tinha a andada dos caranguejos. Aí, eles iam lá em casa buscar nós pra comer caranguejo mais eles. E tinha a Ester filha dele. [...] A Ester todos os anos fazia o carnaval. [...] E lá faziam os três dias de carnaval. As casas deles era mesmo como casa de índio. [...] Agora já têm as casas deles direito. As casas deles eram assim umas palhas assim em pé. Eles punham uns paus assim e colocava assim as coisas. Aí, nessa trave aqui eles colocavam as redinhas dos meninos, assim. (Dona Lúcia, Capoeira, 15/05/1990).

Assim, Perna-de-Pau e sua parentela epitomizavam um tipo de "convivência", ou "sistema de vida", específico e distinto do dos regionais, marcado por várias características: hábitos alimentares, formas de casa, tipos de atividades produtivas (não consideradas trabalho no sentido estrito - termo adstrito à agricultura e às atividades assalariadas), predisposições comportamentais ("não tinham zelo") e vida social em geral. A noção de que os tapebas se caracterizavam - e, em certa medida, ainda se caracterizam - por tal "convivência" é recorrente e presente numa série de testemunhos, constituindo fatores que compunham - e, de certo modo, ainda compõem - o reconhecimento da coletividade. Assim sendo, além da ocupação tradicional do terreno do Paumirim 
(que enfocaremos na próxima seção) e da autoridade coagente, aglutinadora e tradicional de Perna-de-Pau, este corporificaria tal dinâmica, ritmo e estilo de vida, visto pelos próprios tapebas e pelos regionais como característicos dos "troncos velhos", demarcadores do reconhecimento dos tapebas como constituindo uma coletividade distinta.

As transcrições nos permitem entrever, igualmente, um importante referente da adscrição étnica tapeba, que também tem em Perna-de-Pau um representante: o preconceito e o estigma que pesavam contra o grupo e que parecem ter funcionado durante um longo tempo como uma barreira social e ideológica à interação com os regionais, limitando as possibilidades de interação fora da família - no sentido que atribuem a este termo (ver segunda seção) - e intensificando a conexidade das redes de parentes, vizinhos, colegas de trabalho e amigos. As expectativas de conduta desabonadora moldaram durante décadas e, em alguma medida, ainda influenciam a interação dos tapebas com não índios, contribuindo para a consolidação da adscrição étnica e para a sua circunscrição como um conjunto distinto de pessoas a partir de uma referência à sua conduta.

O termo "tapeba" faz sobrevir a referência a determinado ethos e a padrões de conduta desabonadores, que, reconhecem, seus ancestrais efetivamente atualizavam: consumo excessivo de cachaça (quando não, alcoolismo); comer carne velha podre ou carniça; faltar com higiene e cuidados básicos (imundície); incorrer em relações incestuosas (sentido pejorativo do termo "misturada" quando usado por não índios em referência às relações endogâmicas); roubar; e desenvolver atividades produtivas não consideradas como trabalho no sentido convencional do termo (mormente extrativas e em dependência direta dos recursos naturais disponíveis). A adscrição étnica tapeba, portanto, incorpora símbolos de estigma e constitui, ela mesma, um símbolo de estigma - ou "discriminação", como disseram vários deles -, operando mesmo como xingamento em dadas circunstâncias.

Os depoimentos poderiam ser multiplicados indefinidamente e são monocórdios, insistindo sempre nos mesmos pontos: comedores de carniça, preguiçosos, cachaceiros, promíscuos, lascivos, ladrões, desonestos, mentirosos e imundos - a escória, enfim. A força pejorativa desses atributos desabonadores ainda caracteriza, para muitos regionais, os tapebas enquanto um povo distinto. Tais aspectos ainda compõem parte da face pública dos tapebas nas interações 
da vida cotidiana e a memória das condutas de Perna-de-Pau e seus descendentes reforça isso. $\mathrm{O}$ que também explica porque alguns tapebas se esforçam por descaracterizar essa identificação na esfera da vida pública adotando estratégias de assimilação.

\section{Perna-de-Pau e a querela em torno dos terrenos do Paumirim: as tensões da afinidade e a diáspora tapeba}

Vivendo com as irmãs Tereza e Paulina, Perna-de-Pau era, portanto, genro do finado Antônio Jacinto, que - segundo informantes que conheci já bem idosos em minhas primeiras incursões a campo (tal como os finados Avelino e Raimundo "Manivão") - era o antigo dono das terras do Paumirim, antes dos finados Zé Florindo e doutor Luiz Cruz. Os testemunhos são consistentes em assegurar que, antes da diáspora dos tapebas do Paumirim, de sua expropriação e expulsão, que os levou a viver na beira da linha, eles moravam no Paumirim propriamente dito, ocupando parte deste sob a autoridade do velho Perna-de-Pau. Aqui também, o protagonismo de Perna-de-Pau e o modo como ele e a sua cunhada Joana Coco (viúva de seu irmão Antônio Zabel) e seus descendentes conduziram a gestão desse território parecem representar um microcosmo da forma como outros tapebas se comportaram em relação aos seus respectivos patrimônios territoriais. A celeuma e as diferentes versões em torno do que ocorreu a tal patrimônio são significativas para entender o modo como os tapebas (em especial, os Zabel, os Jacinto e os Coco) passaram a viver desde então.

Retornemos ao depoimento de seu João "Padre" - o primeiro testemunho transcrito aqui no artigo. Na continuação daquele seu relato, respondendo a uma pergunta da sua filha, Marlene, presente na situação da entrevista, seu João nos deu a seguinte versão para a expropriação do terreno do Paumirim.

Marlene: Não diziam que esse terreno aí era do velho Perna-de-Pau? João: Esse aqui era do Perna-de-Pau! Mas foi perdido, ele. O velho, foi o tempo que ele perdeu a perna e vivia só de pescar. Passava no Zé Florindo. O Zé Florindo tinha um armazém. Aí ele passava, levava cachaça e comprava pra comer no rio. Voltava, trazia cachaça e comida pra comer em casa. Nisso, quando deu fé, a conta estava grande. Aí o homem tomou conta do terreno. Esse terreno aí. 
[Aponta para a direção da fazenda do senhor Luís Cruz.] Era do Perna-de-pau. Foi tomado dele. Tomado não; ele tirou tudo de conta. E o velho aumentando, aumentando.

M: Naquele tempo terreno não valia, não, dinheiro?

J: Uhum.

M: Se aproveitaram, talvez, da ingenuidade dele. (Paumirim, dezembro de 2002).

Versão relativamente similar já me havia sido contada por Raimundo Francisco da Silva, Raimundo "Manivão", que faleceu em abril de 1988 aos 84 anos. Seu Raimundo não era tapeba, embora corresse a estória de que ele seria filho bastardo do coronel Alfredo Miranda, da lagoa dos Porcos, com uma índia. Ele foi casado com a também finada Maria Luiza Jacinto, que morreu naquele mesmo ano com 88 anos e era irmã de Tereza e Paulina, as mulheres de Perna-de-Pau. O trecho abaixo é de uma curta entrevista com Raimundo "Manivão", em janeiro de 1987. Àquela altura ele já se encontrava "moco" e "broco", ou seja, com surdez progressiva e senil, razão pela qual a entrevista não rendeu muito. Foi realizada na presença de várias netas, que se divertiram animadamente com algumas respostas suas. "Manivão" era tido como mestre na arte de fazer gaiolas para apresar passarinhos, que, como vimos, era uma das práticas tidas como características da convivência tradicional tapeba.

Henyo: Então, o senhor conheceu o Perna-de-Pau e os tapebas todos daqui? Raimundo: Tudo. Eu conheci tudo, tudo, tudo. Tudo. Eu conheci tudinho, tudo, tudo. Eu genro, essa daqui, morava aqui. Esse terreno aqui era do meu sogro. Pai da minha mulher. Zé Florindo tomou de conta. Passou a mão. Vendeu ao dr. Luiz. Isto aqui, no tempo disso aqui, das Capoeira, cansei de tirar tala pra fazer gaiola, viu? Hoje não está mesmo que uma cidade?! Tem gente de toda a província desse mundo.

H: O senhor falou que esse terreno aqui era do seu sogro, Antônio Jacinto?

R: É. Esse terreno ali era. Do Antônio Jacinto.

H: Conta aí como é que foi a história desse terreno até ele parar na mão do dr. Luiz.

R: Os filho que ficou, os filhos não se incomodaram. E o velho passou a mão. Vinte e dois metros da linha, tanto pra cá como pra lá, é do governo. Vinte e dois metros. Dali da linha pra cá dá dezessete. E ninguém não espera mais 
bondade, não, que é isso mesmo. Já foi-se o tempo. É como na cantiga da perua: é daqui pra pior.

Interessante notar o salto dado por seu Raimundo entre a menção ao apossamento por terceiros do terreno do Paumirim, pela suposta desatenção dos filhos de Antônio Jacinto, e a descrição da situação presente onde são obrigados a viver em terreno da União, marginal à estrada de ferro. Ao contrário de seu João "Padre", seu Raimundo não menciona Perna-de-Pau - genro de Antônio Jacinto - como estando entre os que "não se incomodaram", permitindo ao finado Zé Florindo ter tomado conta.

Outro relato que reforça a hipótese de a fazenda de cerca de 40 hectares do dr. Luiz Cruz ter sido apossada de modo doloso e ilegítimo foi oferecido por seu Fernando, ex-presidente da Associação das Comunidades do Rio Ceará pelo lado dos brancos, na qual também representava a comunidade da Capoeira. Refiro-me a um trecho de uma entrevista com ele, realizada em sua casa, em maio de 1990.

O que o seu Raimundo disse a mim lá, é que um trabalhador lá de dentro da fazenda do dr. Luiz Cruz tinha dito a ele, ao seu Raimundo, que o dr. Luiz Cruz estava com medo de perder aquela área de terra para os tapebas. Porque já tinha visto o levantamento da Funai passar lá e ele tinha certeza de que ali não era dele. Ele não tem documento. Um trabalhador de lá, de serviço. Prova que o dr. Luiz só situou mais do lado da pista, né. E do lado do Trilho, do lado dos tapeba, você vê aí. Tá no mato, você não viu lá?

A versão que corria era que o dr. Luiz Cruz teria aplicado um golpe na viúva do finado Zé Florindo para se apropriar do terreno. Há referências tão claras de que essa área teria sido de ocupação tradicional pelos tapebas, que ela findou sendo incluída na TI identificada pela Funai já em 1986 como uma gleba à parte - a TI sendo composta, então, de duas glebas: a Tapeba e a Paumirim.

Que parte expressiva das terras do Paumirim, incluindo uma área adjacente à fazenda do dr. Luiz Cruz ao sul da rodovia BR-222 antigo traçado, estiveram sob a posse mansa e pacífica dos Jacinto e dos Zabel (Antônio Jacinto e Perna-de-Pau), mas também dos Coco, confirma-se por meio de outros depoimentos, como os do finado Avelino Teixeira de Matos. 
Seu Avelino era reconhecido e se reconhecia como sendo "de dentro do tapeba", "de dentro dos troncos velhos antigos", tendo eu concedido especial atenção em entrevistá-lo todas as vezes em que estive em campo. Neto do velho Antônio Jacinto ("pai do meu pai") e filho de Raimundo Jacinto com uma Coco, ${ }^{14}$ seu Avelino era lúcido, atencioso e bem-humorado, mas já apresentava surdez à época, seus testemunhos sendo sinuosos e entrecortados. Em todas as entrevistas, suas netas e filha colaboraram com intervenções esclarecedoras. Já em entrevista entrecortada realizada em 1987 na companhia de sua filha Raimunda, apareceram elementos que permitem caracterizar a distinção entre as formas de apropriação fundiária obtidas no Tapeba e no Paumirim. Em abril de 1990, voltei a entrevistá-lo, tendo ele então 98 anos. Tal entrevista foi conduzida em situação informal, à tardinha, no terreiro da frente da casa de sua filha adotiva, a finada Raimunda Teixeira de Matos, então com 57 anos, situada à época em terreno do sr. Zeca da Costa. Foi acompanhada pela neta de seu Avelino, Lúcia Teixeira de Matos, e pelo marido desta, Chico “Valente", que fizeram intervenções e prestaram esclarecimentos, dada a surdez progressiva de seu Avelino. Nessa entrevista, é importante prestar atenção para as expressões de surpresa de Lúcia e Chico, pois pode-se perceber que a entrevista colaborou na produção de um elo numa genuína cadeia de transmissão oral - já que, segundo seu Avelino, sua lembrança era pouca, "ele ouviu dizer". Chico e Lúcia ouviram confirmada naquela circunstância a história de que parcela das terras do Paumirim tinha pertencido a Antônio Jacinto, avô do seu Avelino e sogro de Perna-de-Pau.

14 Assim sendo, seu Avelino era sobrinho dos finados Maria Luiza Jacinto e Firmino Jacinto, irmãos temporãos do finado Raimundo Jacinto. Não foi possível precisar a mãe de seu Avelino. No levantamento efetuado pela Arquidiocese, em 1986, ele declara o nome de Maria do Espírito Santo, filha de Maria Teixeira Matos, da família Coco, portanto - dado com que trabalhei no diagrama da Figura 4. Na entrevista cujo trecho transcrevo a seguir ele se referiu à sua mãe como irmã de Joana Coco, o que a tornaria filha de João "Mariano" [?] Teixeira de Matos e Francisca Teixeira de Matos - a velha Chica Coco. Independente de qual seja a alternativa precisa - sempre difícil de definir dadas a mistura comum de nomes e sobrenomes formais com apelidos, e as práticas comuns de adoção e união consensual - certamente seria uma Coco, o que atesta a endogenia do grupo, ou seja, a prática de casar na família (conforme referido em seção anterior). 


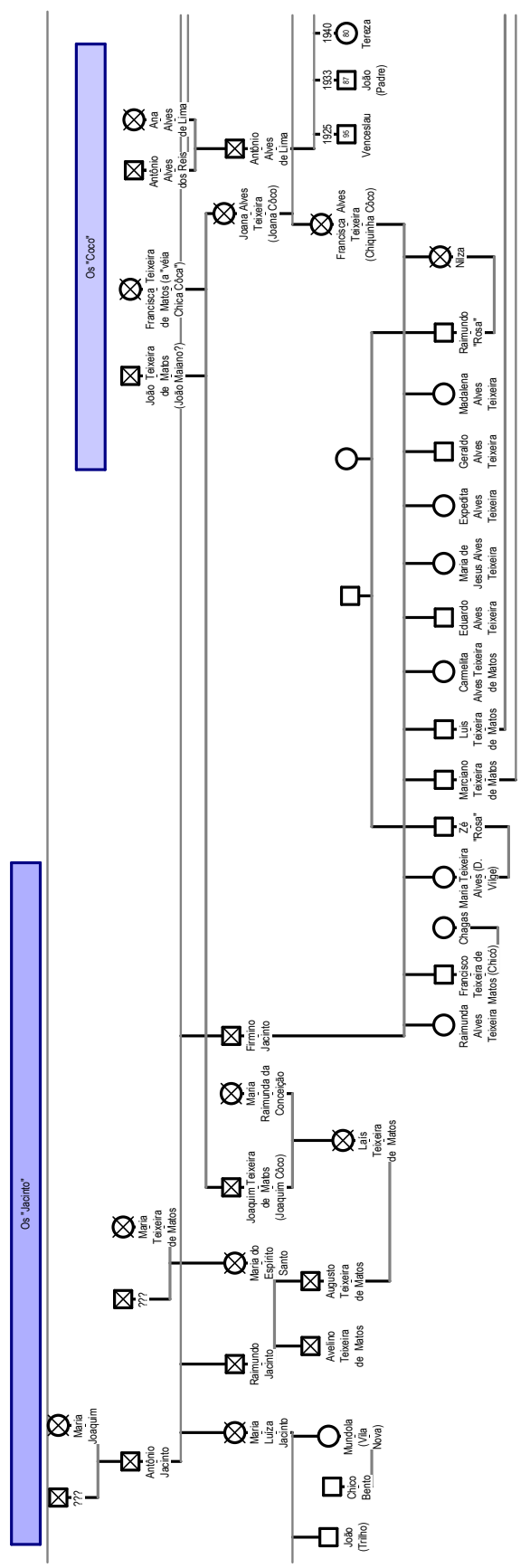

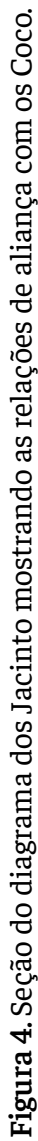


Henyo: O senhor nasceu aonde, seu Avelino?

Avelino: Eu nasci aqui nas Lamas. Num lugar chamado nas Lamas, aqui. Ali onde tem... Onde tem aquele soldado. Ali naquele casão, onde mora aquele soldado. Aquele que mora ali. Soldado.

Lúcia: Em Caucaia?

A: Ah. Aqui ó. Aqui no Capuan aqui.

H: Deve ser na Cancela.

Chico e Lúcia: Na Cancela?

A: Sim, sim. Eu morava mesmo pro outro lado assim, pra acolá. Da Cancela pra cá. Eu morava por ali.

C: Era ali, olha! Está vendo. Na beira da linha mesmo. Aquilo, na minha mente, foi o finado Napoleão que tomou aquele terreno ali. Do Napoleão.

A: Era uma ponta de terra, dizem, que era ainda do finado meu avô. Dizem que ainda era. Tomaram de conta.

C: Olha aí!?

$\mathrm{H}: \mathrm{O}$ que que era do finado seu avô?

A: Terra do finado meu avô. Uma ponta de terra que depois passou pro Zé Florindo.

C: Olha aí, viu?! Ora, rapaz? É do finado Florindo mesmo a história. Viu? Aí o doutor [Luiz Cruz] foi e tomou aquele terreno, parece que comprado por um bico de pão ali. H: Ah, o terreno que é do Oto? O Tatu estava me contando.

C: Não. É do doutor. Ali do doutor, na [Polícia] Rodoviária [Federal].

H: Do seu Luiz Cruz?

C: É.

A: Nesse tempo, nós morávamos ali. É. Depois foi o tempo em que o meu pai embarcou, nós se espalhamos pra aqui e pra acolá. Espalhou-se tudo.

H: Quer dizer, então, qual era a ponta de terreno que era do finado seu avô? Onde ficava?

A: Ali, ali. Naquela... Ali onde hoje tem aquela vacaria. Acolá pra ali. Ali pra baixo. Ali foi o Zé Florindo que tomou de conta. Ali é de muita gente. Foi do Zé Florindo. [...]

H: O senhor saiu de lá pra onde? Depois que o senhor saiu das Lamas, o senhor foi pra onde?

A: Fui pro Tapeba. Fui morar no Tapeba. Agora, do Tapeba foi que eu vim embolar por aqui. [...] 
C: Aí, depois que o vô saiu do Tapeba, veio pra cá, foi?

A: Eu nasci nas Lama. Nasci nas Lama, ali. O povo chamava as Lama. Porque era brejo mermo. Por ali, naqueles matos. Não tenho lembrança, mas eu tinha uma lembrançazinha, muito pouca, pouquinha. Do meu avô, pai do meu pai, o velho Antônio Jacinto. Mas não sei. [inaudível] Ali foi do Zé Florindo, foi não sei mais de quem. Foi da Joana Zabel [também referida como Joana Coco], minha tia. Um pedaço que ele comprou, o Antônio Zabel. Irmã da mamãe, minha tia Joana, morou ali. Foi pro Amazonas. Daí quando veio comprou aquele pedaço de terra dali da estrada pra lá. Comprou aquela parte dali, até fora lá. Ali [inaudível] morreu. Ficou a tia Joana, ela vendeu pra banda de cá. Não sei o que foi que ela fez, só uma partezinha, pouquinha, acho que era uma nesguinha, uma coisinha. Mas pra lá, da estrada pra lá, ela comprou todinha do velho... Depois que chegou do Amazonas comprou até lá embaixo. Era terra grande. Ali venderam, a tia Joana vendeu tudo, os filhos casaram. Aí ela vendeu umas partes de cada um. Repartiu. Encerrou tudo aí. Aí venderam tudinho, acabou. Até o “irmão” Firmino vendeu a parte dele aí.

A trajetória de deslocamento de seu Avelino é semelhante à de alguns antigos habitantes do Paumirim que, após terem perdido a posse de seus terrenos, foram para o Tapeba e retornaram para beira da linha de ferro - o Trilho. Outros "se saíram" para o Açude e para a Cigana, tendo ido depois formar, como primeiros moradores, as localidades conhecidas como Pontes e Vila Nova (Soledade e Santa Rita). Outros, ainda, foram para a Capoeira (Bairro Pe. Júlio Maria). A diáspora tapeba a partir do Paumirim - "espalhou-se tudo", nos termos de seu Avelino - está na origem de muitos grupos locais tapebas contemporâneos.

A entrada na história do irmão de Perna-de-Pau, Antônio Zabel, marido de Joana Coco, complexifica a narrativa sobre as razões da desarticulação do patrimônio territorial do Paumirim, que teria levado à diáspora dos tapebas. A hipótese, aventada por seu Avelino, de que ele teria adquirido uma parte do terreno do Paumirim por compra com as economias que fez cortando seringa no Amazonas é reforçada por vários testemunhos. Raimunda Alves Teixeira, filha mais velha de Firmino Jacinto e Francisca Teixeira de Matos, a Chica "Coca" (filha de Joana Coco), em entrevista de grupo feita com cinco filhos e netos na Escola de Ensino Fundamental Tapeba Diferenciada da Capoeira, em dezembro de 2002, relatou o seguinte. 
Henyo: A senhora chegou a conhecer os avós de vocês, o velho Antônio Zabel e a velha Joana Coco? Chegaram a conhecer eles vivos?

Raimunda: Conheci minha avó. Porque meu avô, quando veio de São Paulo, porque ele trabalhava lá, né? Ele veio de São Paulo. Quer dizer que nesse tempo eu não era gente, não. Mas a minha avó contava. [Ruído ambiente.] A minha mãe contava que o meu avô tinha ido pra São Paulo e lá ele trabalhou e recebeu um dinheiro que deu pra comprar aquele terreno, viu? Meu avô passou muito tempo em São Paulo, que ele trabalhava lá no negócio de seringa, né? Um negócio de seringa. Era. Aí ele trabalhou, ganhou esse dinheiro e comprou aquele terreno. Com poucos dias que o meu avô chegou, ele morreu. Aí, ela ficou viúva. E o tio Marcelino, que era o mais velho, ele ia pra cidade. Cortava aquelas carnaúbas e ia pra cidade vender madeira - essas coisas assim. A minha mãe contava. Ajudou a minha avó a criar os filhos - os irmãos. Mas que o meu avô, quando veio, não durou muito tempo, não. Morreu logo. Aí ela ficou com aquele terreno e ela vendeu uma parte daquele terreno para o Zé Florindo. Quem comprou foi o Zé Florindo - a parte do terreno. Aí ele queria comprar mais. Aí, ela disse: "Não. Eu não posso vender este terreno todo porque tem meus filhos." Aí vendeu uma parte, que era aquela parte da estrada, era do Zé Florindo - um homem que morava em Caucaia. Viu? Ela foi e vendeu. [...] A mãe Joana vendeu. Aí ela disse: “Olhe, seu Zé! Eu vendo" - parece que ele pagou, não sei se foi de duas vezes. “Olhe, seu Zé. Eu só vou vender porque eu tenho que comprar alguma coisa para os meus filhos. Porque meu marido morreu." Mamãe contava, viu? A mãe contava tudinho e eu ouvia, porque eu era a mais velha, né? Aí eu dizia: "Mãe, de que jeito era meu avô?" Ela dizia assim: "Minha filha, o seu avô era moreno da cor do Zé" que era o tio Zé Coco. [...]

Note-se no testemunho de dona Raimunda a referência à cor do seu avô Antônio Zabel, irmão de Perna-de-Pau: "moreno da cor do tio Zé Coco"; o que reforça a suposição, sinalizada por seu João "Padre”, que estamos lidando com um povo os tapebas - que teria incorporado descendentes de negros outrora escravizados em seu seio. Tudo se passa como se o referido Zé Florindo, diante da vulnerabilidade e pressão que sofriam os tapebas do Paumirim, tenha adotado diferentes estratégias para se apropriar daquele patrimônio - seja por mecanismos de endividamento, sugerido por seu João "Padre" para o caso de Perna-de-Pau, seja por compra direta ao velho Antônio Jacinto e à velha Joana Coco. 
Outra neta de Joana Coco, Maria do Carmo "Carminha" Alves do Nascimento, filha do finado pastor João Zabel Alves de Matos, deu o seguinte testemunho em janeiro de 1987, quando tinha então 53 anos, no terreiro de sua casa no Trilho, ao lado de seu marido, Antônio Gomes da Silva (Antônio "Potinho", ou Antônio “Barreira”).

Henyo: Quantas pessoas moravam lá?

Carminha: Espera aí. Morava o papai, o tio Firmino, o tio Zé, o tio Marcelino, o tio Adolfo, a tia Zilda. Isso tudo era morador dali. Tudo morava nesse terreno. Aí se danaram a vender tudo. Papai foi o primeiro que vendeu. Aí depois do papai foi o tio Firmino. Depois do tio Firmino, foi o tio Zé. Depois do tio Zé, foi o tio Marcelino. O tio Adolfo. Tudo morava nesse terreno. E aí tem os filhos deles, que eram o Lulu, Chicó, Raimunda, Raimundinho, Eduardo, Geraldo. Tudo era filho do tio Firmino, né? Do papai lá em casa era eu, a Geralda, o Nenzinho, o Neném, o Moisés, o Francisco. Tudo morava lá nesse terreno. Aí papai pegou, vendeu o terreno e também nós não assinamos nada. Vendeu bem baratinho esse terreno. Vendeu ao coronel Ananias foi por 18 mil, parece. Que ele repartiu pra cada um de nós foram mil cruzeiros nesse tempo. Pois foi. A cada qual dos filhos ele deu esse dinheiro e nós ficamos aí pra cima e pra baixo, pra cima e pra baixo. O papai já morou no Genipabu, do Genipabu agora está morando ali nas Capoeiras e é desse jeito. Nunca comprou um terreno ainda pra ele fazer uma casa pra ele. Só vive assim pra lá e pra cá, tudinho. Nenhum, nem o tio Marcelino, nem o tio Zé, ninguém comprou. Tudo anda assim, a carateu. ${ }^{15}$ Mas por causa deles, né, de ter vendidos os terrenos deles por mais pouco nada.

$\mathrm{H}$ : E todos eram filhos da dona Joana?

C: Tudinho. Tudinho. Tudo é filho da "mãe" Joana.

H: A senhora sabe dizer se foi ela quem deu o terreno pra eles? Como é que essa...

C: Foi o velho que morreu, né? Que era o Antônio Zabel. O Antônio Zabel morreu. Aí ela ficou só. Aí ela deu o terreno pra cada um dos filhos. Aí ela pegou e deu. Aí eles pegaram e fizeram isso. Mas o terreno era dela. [...] Deu a cada um a sua partezinha. Aí ele comprou esse terreno baratinho. Tudo vendeu tudo por um preço só. O preço que o papai vendeu eles venderam também. E agora, hoje em dia, vive tudo desse jeito.

15 "A carateu" é uma expressão local que significa, aproximadamente, vagando, sem rumo, sem norte, sem destino. 
Carminha deixa entrever que no terreno de seu pai moravam todos os seis irmãos, incluindo ela. Mais tarde, tornando a inquiri-la sobre os motivos que levaram seu pai a se desfazer do terreno, ela disse: "Doidice!" Em testemunho posterior, produzido na sala de sua casa no Trilho, em dezembro de 2002, Carminha confirmou essa história, acrescentando informações sobre a paisagem e as características das áreas que se viram obrigados a deixar pela "doidice" de seus pais.

Henyo: Quando a senhora se entendeu, a senhora vivia onde? Qual a lembrança que a senhora tem?

Carminha: É no Paumirim. No Paumirim mesmo. Aí papai pegou e vendeu o terreno. Foi até o coronel Ananias. Aí foi o tio Adolfo e vendeu o dele. O tio Zé, o Marcelino, tudo morava lá. Aí o tio Adolfo vendeu pra esse Chagas. O tio Marcelino, o tio Zé e o tio Firmino, todos venderam pra esse Chagas. Agora o papai foi pro coronel Ananias. E venderam bem baratinho. Papai vendeu o dele, parece que foi por oitenta reais. Não, nesse tempo não era real não. [...] Ficamos desabrigados, né. Aí ele pegou, a cada qual deu um tanto de dinheiro. Deu um tanto a mim, um tanto à Geralda, ao finado Neném. Nós fomos procurar outro meio. Mas cada qual com um pouquinho, porque ele vendeu por pouco. Mais ou menos nada. Aí, até todo mundo dizia assim: “É por que vocês não fizeram questão? Deixaram ele vender! Que isso aí não era pra ele ter vendido. Era pra ele ter dado a cada qual o pedaço de vocês." Mas nós não fizemos questão dele vender. Que nós pensamos: “O pai podia não vender, não. Deixar aí cada qual." “Ah, vendi, está vendido!" [...]

H: Deixaram muita coisa pra trás, dona Carminha?

C: Tinha! Tinha mangueiral. Carregava! O pai tinha um mangueiral que era carregadeiro: manga itamaracá, manga coité, bola de ouro; e as cajazeiras tudo brotava. Era tudo carregado! Era uma beleza o terreno do meu pai. Bom de fruta! Que era tanta manga no chão! Aí o homem tomou conta. Não sei como foi. Aí está, tamparam aquele beco que tinha pra entrar pra lá. Tocaram a cerca no muro, aí ficou o terreno lá.

Os tapebas do Paumirim, portanto, não só perderam suas terras como o acesso aos seus bens de raiz, suas benfeitorias, os frutos do seu trabalho de manejo dos recursos de que dependiam diretamente e a paisagem que construíram e viram 
se modificar. Carminha refere-se ao fechamento do rumo que saía da estrada, ao norte, na direção do sangradouro da lagoa do Capuan e do rio Ceará, ao sul, e que dava acesso à casa de seu pai.

Já Francisca das Chagas "Chaguinha" de Matos, a Chagas do Chicó, que eu conheci quando tinha 75 anos, era filha de Joaquim Teixeira de Matos, o finado Joaquim Coco, irmão de Joana Coco. Ela era casada com Francisco Teixeira de Matos, o Chicó, então com 71 anos, que sendo filho de Firmino Jacinto com Chiquinha Coco, filha de Joana, finda por ser "primo segundo" da esposa. Ele trabalhava como carreteiro, com um carro de mão, na rua de Caucaia, fazendo entregas. Ambos eram crentes e frequentavam o templo da Igreja Pentecostal Deus é Amor, que funcionava na casa do velho Firmino Jacinto, na Capoeira. Nascida no Paumirim e tendo morado no Tapeba antes de vir para o Trilho, numa trajetória similar à de seu Avelino, dona Chagas era uma simpatia de pessoa - qualidade amplamente reconhecida por todos, que a contrastavam com outros "crentes" da beira da linha, em geral tidos por sisudos, antipáticos e fofoqueiros. Em janeiro de 1987, durante uma entrevista que realizei com ela e sua irmã Damiana, então com 54 anos, apareceu a seguinte referência aos terrenos do Paumirim.

Henyo: Mas era tudo aberto?

Chaguinha: Era tudo aberto. Isso aqui era só uma mata pura. Era a mata pura mermo. As raízes era assim, em cima umas das outras, né? Era aí. Entonce, por último, o que eu conheci... O que me diziam, eu não sei, né? Eu também não vou contar uma história certa, eu não sei, né? Eu era mais nova, né?

H: Claro. Mas, então, o que é que diziam pra senhora?

C: Entonce, eu ouvia dizer que esse terreno era do finado Zé Zabel. Entonce, o finado Zé Zabel teve pena da tia Joana, que tinha ficado viúva. Entonce, ele tinha entregado esse terreno pra tia Joana, né? E aí, entonce, a tia Joana era que era a dona por último, né? Ela era que morava com nós. Entonce, ela foi, morreu. E o pessoal, os filhos dela, os genros - que o meu sogro era um deles, que morava no terreno. Aí por último agora ele foi... E todos venderam o terreno todinho.

H: Um pedaço de cada um?

C: Sim. Um pedacinho de cada um. Justamente esse pedaço que eu morava ali, no Paumirim, é daqui da rodoviária, mais pra frente, né? É daquilo ali até lá embaixo. Todas fruteiras que tinha ali era a riqueza dali. Ali tinha dois pés de 
manga. Manga... parece que chamam ela de ouro. Por gosto, de manhã a gente podia olhar em baixo, era docinho de manga. Aquilo ali, era só amanhecer o dia, eu pegava minha caixinha, enchia ali e seguia pra cidade. Mais tarde, chegava lá na praça São Sebastião, botava no chão, os fregueses compravam. De repente eu voltava pra casa. Pé de manga é uma coisa linda mermo.

H: Além da senhora, quem é que mais morava aí dos filhos da Joana?

C: Era muita gente. Era 13 filho, 13 filho dela. Entre homes e mulheres tudo morava aí nesse Paumirim. [...]

Damiana: É. Morreu tudo. Os mais velhos morreram tudo.

C: Eles gostavam muito de cachaça, né? Bebiam muito e era aquela zoada. Lá do Paumirim, nós morava lá do outro lado, só ouvia a zoada deles aqui. Aquela farofa deles. Assim. Negócio de cachaça mermo, né?

Segundo a versão de Chaguinha, portanto, a parte de terra de Joana Coco, que hoje está majoritariamente em mãos de não índios, teria sido dada a ela por seu cunhado Perna-de-Pau, quando ela enviuvou de Antônio Zabel, tendo ela permanecido no terreno com o consentimento do cunhado.

Temos, então versões relativamente discordantes sobre parte do terreno do Paumirim: ou teria sido comprada por Antônio Zabel assim que este retornou de sua vida como seringueiro, ou teria sido dada por Perna-de-Pau a Joana Coco quando esta enviuvou de Antônio Zabel, tendo ela ali permanecido com seu consentimento, até se desfazer parcialmente por venda direta, ou tendo seus herdeiros paulatinamente negociado suas heranças. Tais versões parecem vincular-se a relatos variantes sobre a relação entre Perna-de-Pau e sua cunhada, que pode não ter sido amistosa. Eu mesmo não registrei nenhum testemunho nesse sentido, embora tenha identificado nas Pontes e na Vila Nova certa animosidade com relação aos descendentes de Joana Coco, que teriam se desfeito das últimas parcelas de terras dos tapebas. Aliás, já em 1986 uma variante dessa versão prevalecia no relatório de Rita Almeida (1986, p. 18), ancorada também em depoimento.

Ipaumirim [sic] foi um lugarejo localizado no distrito de Capuan, onde viveu Antônio, Joana e várias famílias tapebas. Quando Antônio morreu, Perna-de-Pau procurou reaver o terreno, encontrando franca oposição de Joana e 09 descendentes. Joana permaneceu no terreno com o consentimento do cunhado. Mais 
tarde os descendentes de Joana venderam o terreno alegando que sofriam pressões de fazendeiros. A venda provocou profundos desentendimentos entre os parentes persistindo ainda hoje nas relações pouco amistosas entre as famílias Alves de Matos, que descendem de Antônio, e Alves Texeira, do [seu] irmão Perna-de-Pau.

“Quem comprou esse terreno foi João Crisótomo (ou Crisólito). Meu pai não era casado no civil. Então, o velho (Perna-de-Pau) procurou ver se tomava esse terreno. Alguém dava na cabeça dele que ele tinha esse direito... Até hoje os mais novos têm uma inquisição conosco (Alves de Matos) dizendo que tomamos terrenos deles. Mas o terreno foi meu pai quem comprou..."

As "inquisições" mencionadas pelo(a) interlocutor(a) anônimo(a) de Almeida, ou seja, os desentendimentos ou relações pouco amistosas, se é que podem ser caracterizadas desse modo, não se traduzem necessariamente em oposição e/ou conflito abertos e explícitos, segundo pude observar, constituindo antes uma tensão latente e potencial típica das relações entre afins: os grupos de cognatos de Zé Zabel Perna-de-Pau e da sua cunhada Joana Coco. Embora Almeida não identifique seu/sua interlocutor(a), é possível supor tratar-se de um descendente de Antônio Zabel e Joana Coco.

Concluindo, por meio do cotejo entre testemunhos orais relativamente concordantes de vários interlocutores, homens e mulheres de idade avançada e iletrados, e independentemente das distintas versões, foi possível caracterizar o Paumirim como território tradicional tapeba. ${ }^{16}$ Os Zabel, os Jacinto e os Coco se apropriavam de extensa área indo das imediações da estrada de ferro ao norte - onde dominavam Perna-de-Pau, genro de Antônio Jacinto, e seus descendentes - ao rio Picú (rio Ceará) ao sul - de domínio de seu irmão e sua cunhada, e seus descendentes. Os testemunhos também são relativamente concordantes quanto ao modo como estabeleceram esses domínios: o primeiro por legado do sogro e o segundo por aquisição. Isso explica por que o Paumirim é reivindicado pelos Zabel, Jacinto e Coco como terra tradicionalmente

16 Há, também, suporte documental para essa caracterização que converge com a tradição oral, como revelou pesquisa realizada no cartório do registro de imóveis do município para parte de herança do espólio de Antônio Alves dos Reis e sua mulher Joana Teixeira de Matos, formal de partilha datado de 15/03/1984 - o que me permitiria detalhar ainda mais todas essas evidências (ver Barretto Filho, 2005, p. 101 e ss.). 
ocupada pelos tapebas e foi formalmente identificado como tal. Não obstante, salvo por pequenas áreas retomadas pelos tapebas do Trilho, o Paumirim está hoje majoritariamente em mãos de não indígenas.

Em se tratando de áreas ocupadas por distintos grupos de cognatos, é sintomático termos distintas versões de como os domínios de Perna-de-Pau, Antônio Jacinto e Joana Coco no Paumirim foram apropriados por terceiros, tais como Zé Florindo, Luiz Cruz, Chagas, Ananias Rego Castro e outros. Todas realçam, contudo, que os tapebas foram objeto de transações lesivas. João "Padre" sugere que Perna-de-Pau acabou com o terreno em dívidas contraídas no armazém do Zé Florindo com mantimentos e cachaça, e que após a morte daquele os tapebas do Paumirim se dispersaram. Os finados Avelino, Raimunda, Chaguinha e Carminha mencionam que Joana teria vendido parte do terreno de Antônio Zabel para Zé Florindo - "uma partezinha, pouquinha, uma nesguinha, uma coisinha", segundo o primeiro - para ajudar a sustentar a família após a morte do marido. Correm também relatos concordantes sobre como o Luiz Cruz de Vasconcelos se apropriou da área de 40 hectares, que hoje corresponde à sua fazenda, por meio de um ardil aplicado à viúva do finado Zé Florindo. Por fim, os filhos e filhas, noras e genros de Antônio Zabel e Joana Coco aos poucos foram se desfazendo das parcelas que sua mãe lhes legou.

Pode-se concluir que a alienação paulatina de parte desse patrimônio foi uma estratégia relativamente comum de acomodação de famílias tapebas à situação de grupo subalterno e vulnerável ao preconceito, ao estigma e à consequente falta de oportunidades, que não as oferecidas pela sua economia agroextrativista, pois só recentemente granjearam proteção oficial. Daí a referência à diáspora que teria ocorrido com a morte do velho Zé Zabel (que, como vimos, zelava pela conformidade do grupo residente no Paumirim, obstaculizando alianças e uniões interétnicas, e cuidando para que ninguém de fora, nenhum branco, casasse dentro do grupo e impusesse autoridade) e de Joana Coco, com os descendentes de ambos se desfazendo aos poucos de seus domínios. As trajetórias de seu Avelino e Chaguinha, deixando o Paumirim nessa época em direção ao Tapeba e depois retornando às margens da estrada de ferro, e de outros que se espalharam para demais áreas, são centrais para compreender o modo como os tapebas - descendentes ou não de Perna-de-Pau constroem sua história, e que surge nos depoimentos tanto deles quanto dos regionais. 


\section{Considerações finais}

É difícil estabelecer com precisão o ano da morte de Perna-de-Pau, fato importante, pois, como vimos, impactou a vida dos tapebas no Paumirim. Tudo indica que ele viveu até meados do século XX.

De acordo com os dados do cadastramento da arquidiocese, seu filho Geraldão teria nascido em 1942 e, segundo o próprio, não foi criado pelos tapebas, tendo saído de casa com idade de três anos para ser criado por outra família e retornado aos 12 anos, quando voltou para o poder de seu pai. Ainda segundo Geraldão, ao voltar, ele teria morado no Trilho com seu pai por quatro anos, só saindo do Trilho quando seu pai e sua mãe morreram. Se esses dados procedem, Perna-de-Pau teria morrido entre 1954 e 1958. Seu depoimento, contudo, é ambivalente: ao mesmo tempo que diz ter retornado ao poder de seu pai com 12 anos, portanto em torno de 1954, mencionando que vendiam lenha na Caucaia, ele diz que não era Caucaia naquela época, mas Soure. Ora, Soure voltou a chamar-se Caucaia em 1943, portanto 11 anos antes. ${ }^{17}$ Pelo depoimento de Zuíla de janeiro de 1987, quando o velho morreu o máximo que ela podia ter era 12 anos. Sendo ela de 1938, a morte de Perna-de-Pau teria sido cerca de 1950. Já pelas informações de Domingos Flor e Luiza - ela tapeba, sobrinha da finada Joana Coco -, em depoimento de janeiro de 1987, quando eles chegaram para morar no Trilho estava com dois ou três meses que ele tinha morrido. Àquela época, eles afirmaram morar no Corte há 41 anos, o que situa a morte de Perna-de-Pau em torno de 1946.

Em meados do século XX, portanto, entre 1945 e 1958, teria falecido Perna-de-Pau, o velho cacique da aldeia do Trilho de Ferro. Após sua morte, como vimos, os tapebas contam que o grupo que vivia reunido sob a sua autoridade no Paumirim saiu em diáspora, tendo uma parte migrado para o Tapeba e, depois, retornado para as margens da estrada de ferro, outra se estabelecido no próprio mangue onde pescavam (em condições bastante precárias), e outra ainda se dispersado por grupos locais então periurbanos, como Açude, Cigana,

17 Isso não quer dizer muita coisa por dois motivos: (i) a adoção de um novo topônimo administrativo pela população local não é algo que ocorra da noite para o dia; e (ii) o registro do nascimento de Geraldão em 1942, feito por sua família de adoção, deve ter sido tardio, como de resto o de boa parte da população tapeba e não indígena com a qual convivi, que dependia, nessa matéria, até recentemente, de favores dos políticos (vereadores) locais. 
Grilo, Itambé e Capoeira - em alguns destes (hoje bairros da cidade de Caucaia) como seus primeiros habitantes. Se em vida Perna-de-Pau foi um agente aglutinador, sua morte deflagra a diáspora dos tapebas do Paumirim, que, por sua vez, de território relativamente endogâmico se converte em ponto de dispersão e lugar de origem de muita das atuais aldeias. Mudança de trajetória, transformação da convivência e das relações e configurações sociais mais amplas.

Perna-de-Pau não parece ter sido e nem é lembrado propriamente como um "herói", mas como um líder potente, influente e deste mundo, com todas as suas virtudes e vícios, fortalezas e contradições - um sujeito histórico completo, nos termos de Pacheco de Oliveira. Suas condutas características são ainda hoje tomadas como sínteses expressivas de certo modo de vida peculiar ao povo tapeba - melhor dizendo, aos "troncos velhos" dos quais brotaram as "pontas de rama". Sua trajetória, por sua vez, é uma janela pela qual podemos observar as transformações mais gerais pelas quais o povo tapeba passou na primeira metade do século XX. Entre estas destacam-se: a experiência de viver por um tempo longe de sua terra natal, absorvendo influências de outros mundos; 0 arranjo matrimonial que manteve (hoje em desuso) e o grupo de cognatos que assim gerou, no seio do qual exerceu sua liderança (que hoje se exerce de outras formas); e a posse plena, mansa e pacífica de um patrimônio territorial coletivo do qual foi expropriado.

Sua autoridade e influência foram tamanhas, que, com a sua morte e a consequente dissolução do patrimônio territorial, sobrevieram várias mudanças na vida dos tapebas da região do Paumirim. A diáspora dos tapebas e a formação de distintos tipos de assentamento humano situados em diferentes áreas/ regiões/habitats/ecossistemas abarcados pelo município de Caucaia - o mangue, o sertão, os tabuleiros litorâneos, as zonas periurbanas, as terras públicas marginais à ferrovia - resultam do fenecimento da sua influência, de seus contemporâneos e de seus descendentes imediatos, pois, pelo que deixam entrever as narrativas, ele não teria sido sucedido por ninguém de igual quilate. A partir daí proliferam referências a distintas lideranças - pessoas de referência e autoridade - nos diferentes outros sítios que os tapebas estabeleceram. Alguns dos quais, como o cacique Alberto, nas Pontes, de algum modo vinculados ao legado material e simbólico de Perna-de-Pau.

Tudo se passa como se após uma época relativamente áurea de expressão consentida de suas peculiaridades étnicas no Paumirim, na primeira metade 
do século XX, os tapebas, após a morte de Perna-de-Pau, tenham entrado num período de relativa invisibilidade, até sua (re)descoberta, cerca de uma geração mais tarde, no final dos anos 1960, por jornalistas e correspondentes de grandes jornais baseados em Fortaleza.

Procurei, assim, neste exercício híbrido de biografia social, análise de trajetória e etnografia histórica, construir uma narrativa com certa organização e consistência a partir de um conjunto de testemunhos coproduzidos em conversas e entrevistas com meus interlocutores tapebas em diferentes contextos de pesquisa de campo. Ao dar forma escrita à tradição oral em torno de Perna-de-Pau, assumi o desafio e os riscos inerentes de, nos termos de Vansina (1965, p. 21 e ss.), fixar quiçá o primeiro registro escrito, como "registrador" (recorder) relativamente autorizado. Motivou-me o anseio de dar-lhe visibilidade além da esfera local e ampliar o conhecimento sobre ele e os dilemas do seu povo. Assim fazendo, pondo para dialogar vários interlocutores nesta narrativa de narrativas, recorrendo aqui e ali a fontes documentais, espero ter conseguido também dar conta dos diferentes contextos e processos sociais por meio dos quais Perna-de-Pau e seu povo devieram o que são.

\section{Referências}

ALBERT, B. Postscriptum: quando eu é um outro (e vice-versa). In: KOPENAWA, D.; ALBERT, B. A queda do céu: palavras de um xamã yanomami. São Paulo: Companhia das Letras, 2015. p. 512-549.

ALMEIDA, G. G. de. Perna de Pau. In: ALMEIDA, G. G. de. Heróis indígenas do Brasil: memórias sinceras de uma raça. Rio de Janeiro: Cátedra, 1988. p. 103.

ALMEIDA, R. H. de. Relatório de viagem ao município de Caucaia, Ceará. Brasília: Coordenadoria de Terras Indígenas do Ministério da Reforma e do Desenvolvimento Agrário (CTI/MIRAD), 1986.

BARRETTO FILHO, H. T. Tapebas, tapebanos e pernas de pau: etnogênese como processo social e luta simbólica. 1993. Dissertação (Mestrado em Antropologia Social) - Museu Nacional, Universidade Federal do Rio de Janeiro, Rio de Janeiro, 1993.

BARRETTO FILHO, H. T. Relatório circunstanciado de identificação e delimitação da TI Tapeba. Brasília: Funai, 2005. Mimeografado. 
BENJAMIN, W. O narrador: considerações sobre a obra de Nikolai Leskov. In: BENJAMIN, W. Obras escolhidas: magia e técnica, arte e política: ensaios sobre literatura e história da cultura. 2. ed. São Paulo: Brasiliense, 1985. p. 197-221.

BOSI, E. Memória e sociedade: lembrança de velhos. São Paulo: T. A. Queiroz Editor, 1979. BOTT, E. Família e rede social. Rio de Janeiro: Francisco Alves, 1976.

BOURDIEU, P. A ilusão biográfica. In: AMADO, J.; FERREIRA, M. de M. (org.). Usos e abusos da história oral. Rio de Janeiro: Ed. FGV, 2002. p. 183-191.

OS BRASIS e suas memórias: os indígenas na formação nacional. Rio de Janeiro: [s.n.], 18 abr. 2017. Release.

HALBWACHS, M. A memória coletiva. São Paulo: Vértice: Revista dos Tribunais, 1990.

HANDLER, R. On dialogue and destructive analysis: problems in narrating nationalism and ethnicity. Journal of Anthropological Research, v. 46, n. 2, p. 171-182, 1985.

JIMENO SANTOYO, M. Narraciones, historias de vida, autobiografías. In: JIMENO SANTOYO, M. Juan Gregorio Palechor: historia de mi vida. Bogotá: Facultad de Ciencias Humanas, Universidad Nacional de Colombia, 2006. p. 33-52.

MAC | Museu da UEPB em Campina Grande terá obra de Portinari avaliada em R\$ 5 milhões. Grande Campina, 1 jun. 2012. Disponível em: http://www.grandecampina. com.br/2012/06/mac-museu-da-uepb-em-campina-tera-obra.html. Acesso em: 10 set. 2019.

MARIA LÚCIA vê fantasia na origem dos índios Tapeba. Contesta demarcação das terras e teme provocação de conflitos. O Povo, Fortaleza, 17 ago. 1987. Política, p. 4.

MELATTI, J. C. Como escrever palavras indígenas?. Revista de Atualidade Indígena, Brasília, ano 3, n. 16, p. 9-15, 1979.

MELATTI, J. C. Nomes de tribos. Ciência Hoje, v. 10, n. 56, p. 2-3, 1989. Seção “Cartas dos Leitores".

PACHECO DE OLIVEIRA, J. Ensaios em antropologia histórica. Rio de Janeiro: Editora UFRJ, 1999.

SAHLINS, M. Goodbye to Tristes Tropes: ethnography in the context of modern world history. Journal of Modern History, v. 65, n. 1, p. 1-25, 1993. 
SAMPAIO, D.; COSTA, F. J. L. da. Anuário do Estado do Ceará. Fortaleza: Stylus - Consultoria de Investimento, Publicidade e Planejamento, 1972.

VANSINA, J. Oral tradition: a study in historical methodology. Harmondsworth: Penguin Books, 1965.

Recebido: 30/09/2019 Aceito: 27/04/2020 | Received: 9/30/2019 Accepted: 4/27/2020 